\title{
Government Deficits in the European Union: An Analysis of Entry and Exit Dynamics
}

\author{
ALI BAYAR \\ BRAM SMEETS \\ CESIFO WORKING PAPER NO. 2703 \\ CAtegory 6: Fiscal Policy, Macroeconomics and Growth \\ JULY 2009
}

\footnotetext{
An electronic version of the paper may be downloaded

- from the SSRN website: Www.SSRN.com

- from the RePEc website:

www.RePEc.org

- from the CESifo website:

www.CESifo-group.org/wp
} 


\title{
Government Deficits in the European Union: An Analysis of Entry and Exit Dynamics
}

\begin{abstract}
The extent of government deficits and debt has been one of the most debated issues in recent years. However, much less has been contributed about their dynamics. Yet, the issue of entering into and exiting from excessive deficits is critical in the Economic and Monetary Union since the Stability and Growth Pact rules out deficits larger than 3 percent of GDP, unless countries face strictly defined unusual conditions. This paper provides a transition data analysis of the dynamics of public deficits. It shows the asymmetric role played by the economic determinants in these dynamics and estimates the evolution of the probability of entering into and exiting from excessive deficits for every individual member state of the European Union that signed the Maastricht Treaty, since 1970. It also reveals how the concurrence of some minor changes may produce a major switchover in public finance outcomes. Finally, it analyses the evolution over time of the probabilities that countries will enter or escape from the state of having excessive deficit, and hence the fragility of some countries even if they are now out of excessive deficits.
\end{abstract}

JEL Code: C41, E60, H60, H87.

Keywords: fiscal policy, Economic and Monetary Union, duration models.

Ali Bayar

Free University of Brussels and EcoMod

Avenue F.D. Roosevelt, 50

C.P. 140

Belgium - 1050 Brussels

Ali.Bayar@ulb.ac.be
Bram Smeets

EcoMod

Belgium - Brussels

bram.smeets@ecomod.net

March 2009 


\section{Introduction}

Fiscal discipline and fiscal restructuring have been among the most debated issues in recent years, more particularly in relation to the establishment of the Economic and Monetary Union (EMU) and the related requirements that are imposed on the participants, and to the balancedbudget rule in the US. Three major questions have been at the heart of this debate:

- If discretion in policy making may lead to high public deficits and debt, should policymakers be subject to strict fiscal constraints? What are the costs and benefits of fiscal rules?

- What role do economic, political and institutional variables and processes play in the public finance outcomes?

— What are the macroeconomic effects of fiscal adjustments?

A growing theoretical and empirical literature is devoted to the analysis of these questions. Buiter et al. (1993) and Roubini (1995) examine the relevance of fiscal constraints and claim that rigid fiscal rules deprive the policy maker of an important tool to stabilize output and smooth tax distortions over time. Mainly focussing on the second question, Roubini and Sachs (1989), Grilli et al. (1991), Alesina and Perotti (1995), and Alesina and Perotti (1996) show the importance of political and institutional factors in public finance outcomes. Von Hagen (1992), Alesina and Perotti (1996a and 1996b), and Poterba (1996) consider the role of institutions and procedures involved in the process of preparing and approving the budget. Corsetti and Roubini (1996) compare the European and American fiscal rules. Poterba (1996), Bohn and Inman (1996), and Ahmed (1996) discuss the effectiveness of balanced-budget rules in the US states. Regarding the third question, Bartolini et al. (1995), Bayar et al. (1997), Hallett and Adam (1997), and Cour et al. (1996) evaluate the macroeconomic impacts of fiscal adjustments and rules using econometric models. Alesina and Bayoumi (1996), and Bayoumi and Eichengreen (1995) explore the implications of fiscal rules on economic stabilization. Bertola and Drazen (1993), Giavazzi and Pagano (1990 and 1995), Barry and Devereux (1995), McDermott and Wescott (1995) discuss whether contractionary policies may have expansionary effects. Alesina and Perotti (1995 and 1997), and Perotti (1996) show that the composition of fiscal consolidation matters for the success of fiscal adjustments. Heylen (1997) discusses the effectiveness of fiscal consolidation policies in 19 OECD countries since the mid-1970s. 
Since the ratification of the Maastricht Treaty in 1993 and the subsequent enforcement of the Stability and Growth Pact $^{2}$ (SGP) of the EMU in 1999. these agreements have been subject to numerous debates and criticisms that can usually be categorised in at least one of the three categories listed above. Due to the recession and following negative budgetary developments in the majority of the member states early in the new millennium, the discussion on the costs and benefits of fiscal rules and constraints gathered momentum. Ballabriga and Martinez-Mongay (2005) evaluate the sustainability of public finances in a country set including the EU, both before and after 'Maastricht'. Based on a model that considers long-term solvency of public finances as criterion for sustainability, they find that the major part of member states in the EU pursued sustainable fiscal policies both before and after the enforcement of the Maastrichtcriteria. Addressing the third question, Buti et al. (2007) investigate the effects of fiscal rules in relation to structural reforms, as formulated in the Lisbon Agenda enhancing economic growth and an increase in employment. They compare the two opposite views that either these two policies are supportive to each other or that they are incompatible and governments face the dilemma of focussing on one and harming the other.

As a response to the many criticisms, numerous proposals have been formulated for improving the SGP. Fischer et al. (2006) present a comprehensive overview and categorisation of these proposals, and identify main factors that are considered to be the cause of the vulnerability of the SGP to the various criticisms. Next to the crisis of the SGP during the recession after 2001 . and other changed circumstances, as main explanation for the variety in proposals they identify the lack of consensus about the role of fiscal policy. In general, the recent macroeconomic literature on fiscal policy is remarkably rich and especially in relation to the European integration process, many contributions have brought better understandings but also larger contradictions concerning the determinants of public deficits. However, apart from the existing disagreement, the debate has, until now, largely focused on the magnitude of government deficits and debt alone. An important issue has received considerably less attention: the dynamics of deficits.

The dynamics of government deficits are of utmost importance in the monetary union because the European Stability and Growth Pact, which has been guiding fiscal discipline among the member states after the introduction of the Euro on January 1. 1999. explicitly rules out deficits above 3 percent of GDP, unless countries face precisely defined unusual circumstances. Since

\footnotetext{
${ }^{2}$ The Stability and Growth Pact defines precisely under which conditions and following which steps the Excessive Deficit Procedure will be launched against a member state which does not comply with the ceiling of 3 percent of deficit to GDP ratio. The Pact also states that in the medium run the budget should be close to balance or in surplus such that the deficit to GDP ceiling of 3 percent can even be observed under unfavourable economic situations.
} 
the Stability and Growth Pact establishes a legal definition of excessive deficit ${ }^{3}$ that the member states should avoid, it is important to examine the entry and exit dynamics of excessive deficits. How do countries enter into deficits qualified as being excessive, or, if a country has excessive deficits, how does it exit from such a situation? What are the risks of entry and exit for different member states? These questions are essential for the European Economic and Monetary Union because the member countries will lose the exchange rate as a macroeconomic adjustment mechanism and will have to rely on fiscal instruments ${ }^{4}$. The dynamics of excessive deficits and its determinants are therefore a vital issue.

Recently, several studies have focused on these dynamics behind fiscal consolidation - i.e. exiting from the state of excessive deficits and continuing this situation. In order to evaluate the length of different spells together with the probabilistic process driving the particular changes of states, most studies present transition data analyses. (Lancaster, 1990) The econometric methods of transition data (or survival) analysis are particularly well suited for this issue because one is concerned both with the duration of a $\operatorname{state}^{5}$ and the destination ${ }^{6}$ that is entered at its end. Transition data refers not only to how long a state lasts but also to what happens when it ends, and besides it provides an elegant tool to parametrically analyse the explanatory forces behind the process.

In one of the first approaches to apply the methodology from survival analysis to the field of public finance, Von Hagen et al. (2003) use a parametric ${ }^{7}$ hazard model to model duration endogenously, and estimate the impacts of different economic circumstances on the persistence of budgetary consolidation in a set of industrialised OECD countries. Particularly focussing on experiences in Europe during the 1990s, they find weak evidence for a contribution to persistence of budgetary consolidation by the Maastricht treaty. Gupta et al. (2003) focus on emerging markets instead, and present both parametric, semi-parametric and non-parametric analyses of the duration of fiscal consolidations. Besides, they use a broad definition of fiscal consolidation in their analysis, capturing both the pace of deficit reduction and the 'critical' level of deficit.

\footnotetext{
${ }^{3}$ In this paper we use the term 'excessive deficit' in its legal sense established by the Stability and Growth Pact, and not in any economic meaning. It is clear that there is no economic standard to know whether a given deficit is excessive or not. Following the threshold laid-out by the Stability Pact, in this paper, deficits above three percent of GDP are classified as being 'excessive'.

${ }^{4}$ As well as on wage and price changes.

${ }^{5}$ Being in or not being in a state of excessive deficit.

${ }^{6}$ Excessive or non-excessive deficit states.

${ }^{7}$ A parametric model pre-assumes a particular parametrised probability distribution underlying the stochastic process, whereas in a non-parametric model, this distribution depends on the data.
} 
Adam and Bevan (2003) apply a semi-parametric duration analysis to two sets of countries, and compare the findings for 25 OECD countries to the results of the analysis of 50 developing countries. They find that, when (initial) income levels differ, different factors are determinant for the persistence of fiscal consolidation. Illera and Mulas-Granados (2002) compare different duration models in order to find the one that is most appropriate to evaluate the duration of different episodes of fiscal consolidation in 15 countries in the European Union from 1960-2000. Using both economic and political variables as covariates in their model, they evaluate the probability of ending a period of fiscal consolidation.

The vast majority of the literature has in common that only periods of fiscal consolidation are analysed, and the probability of ending such a period is evaluated - i.e. the probability that a country runs into excessive deficits after it experienced a reduction of deficits or alternatively managed to keep its deficit below a certain threshold. However, it is also of great interest to evaluate the probability of a reverse change: after a period of excessive deficits, how and why does a country manage to reduce its deficit again by a sufficient extent. Especially under the European Stability and Growth Pact, it seems a plausible assumption that most countries pursue an effective consolidation policy, at least to the extent that as a standard they succeed in keeping their deficit below three percent of GDP. Therefore, it is useful to evaluate how, starting from a deficit smaller than this threshold, different determinants have an impact on the risk of entering the state of excessive deficit. However, given the strict regulations and penalties that the participating countries face, it is also interesting to see what the determinants are of a successful exit of excessive deficit, once one has passed the threshold. Bayar (2001) evaluates both entry and exit dynamics into and from the state of excessive deficit, and finds that indeed, the impacts of different economic covariates are asymmetric between the two models.

Following Bayar (2001), this paper provides a transition data analysis of the dynamics of budget deficits in the 15 member countries of the European Union that signed the Maastricht treaty in 1992. Using data for the period 1970-2006. in this paper I examine the economic determinants of entry and exit dynamics of excessive deficits and estimate the hazard rates for each one of the member states. The remainder of the paper is organized as follows. The transition model is presented in section 2. Section 3 provides the econometric results. Section 4 concludes. 


\section{A Transition Model}

The evolution of nominal government deficits $(D E F)$ can be expressed by the accounting relation

$$
D E F_{t}=D_{t}-D_{t-1}=E_{t}+i D_{t-1}-T A X_{t}
$$

where $D$ is the stock of public debt, $E$ is government primary expenditure, $i$ is the nominal interest rate on the debt and $T A X$ is total revenues.

Expressing the nominal deficit in terms of GDP gives

$$
\frac{D E F_{t}}{Y_{t}}=\frac{E_{t}}{Y_{t}}+\frac{1}{(1+g)(1+\pi)} \frac{i D_{t-1}}{Y_{t-1}}-\frac{T A X_{t}}{Y_{t}}
$$

where $Y$ is GDP, $g$ is the growth rate of real GDP, and $\pi$ is the inflation rate.

Equation (2) clearly shows that the deficit-to-GDP ratio increases with government spending, nominal interest rate and debt stock, whereas it decreases with the growth rate, the inflation rate and government revenue. Equation (2) can be used to analyze how various economic variables determine the evolution of the deficit-to-GDP ratio.

One of the critical questions which arise with the criterion of 3 percent of the Maastricht Treaty and the Stability and Growth Pact is how the deficit-to-GDP ratio evolves with respect to this threshold of 3 percent. In order to examine this question let us define two states $s_{1}$ and $s_{2}$ for the deficit-to-GDP ratio. $s_{i}$ is a discrete binary variable: the state of being in excessive deficit (deficit-to-GDP ratio $>0.03$ ) and the state of not being in excessive deficit (deficit-to-GDP ratio $\leq 0.03)$. Now, the question is: How do countries enter into and exit from such states? What are the effects of various economic variables on these entry and exit dynamics?

Let us think of time to exit the state $s_{i}$ as a continuous random variable $T$. $T$ can be considered as the duration of stay in the state $s_{i}$ if we set the clock to zero at the moment a country enters into the state in question. Then, the probability of exiting the state $s_{i}$ in the time interval from $t$ to $t$, given that the country has been in that state up to time $t^{\prime}$, can be defined as: 


$$
P_{i}\left(t \leq T<t^{\prime} \mid T \geq t\right) \quad t<t^{\prime}
$$

This is the probability that an event (entry or exit) occurs in the time interval from $t$ to $t$, given that no event (transition) has occurred before in the interval from 0 to $t$. The definition refers to each point in time and can therefore describe the temporal evolution of the process.

If we divide this probability by $t-t^{\prime}$, we get the average probability of leaving per unit time period over a short interval after $t$. By considering this average over shorter and shorter intervals we get the hazard function $h_{i}(t)$ of dynamics for state $s_{i}$

$$
h_{i}(t)=\lim _{t^{\prime} \rightarrow t} \frac{P_{i}\left(t \leq T<t^{\prime} \mid T \geq t\right)}{t^{\prime}-t}
$$

The interpretation of the hazard function is that $h_{i}(t)(t-t)$ is approximately the probability of exit from the state $s_{i}$ in the short interval after $t$, given that the country has still been in state $s_{i}$ at $t$. We can also interpret $h_{i}(t)$ as the propensity to change the state, from the origin state $j$ to the destination state $k$, at $t$. But it should be kept in mind that this propensity is defined in relation to the risk set at time $t$, i.e. the set of countries which are still in the origin state $j$.

We can express the hazard function in terms of the distribution and probability density functions of the random variable $T$. Let the distribution function be

$$
F_{i}(t)=P_{i}(T<t), \quad t \geq 0 .
$$

This gives the probability that an event happens (exit from or entry into the excessive deficit state) in the time interval from 0 to $t$. Equally, we can describe the probability distribution of $T$ by a survivor function $G_{i}(t)$ :

$$
G_{i}(t)=1-F_{i}(t)=P_{i}(T \geq t)
$$

This is the probability that the spells duration is at least $t$, that the exit from state $j$ and entry into state $k$ occurs later than $t$. 
The distribution of the random variable $T$ can also be described by a density function, $f_{i}(t)$, which is related to the distribution function by

$$
F_{i}(t)=\int_{0}^{t} f_{i}(u) d u
$$

Now, we can establish the relationship with the hazard function.

By the law of conditional probability we have

$$
P_{i}\left(t \leq T<t^{\prime} \mid T \geq t\right)=\frac{P_{i}\left(t \leq T<t^{\prime}\right)}{P_{i}(T \geq t)} .
$$

In terms of the distribution function, this is equivalent to

$$
\frac{F_{i}\left(t^{\prime}\right)-F_{i}(t)}{1-F_{i}(t)}
$$

Dividing this expression by $t$ - $t$ and getting the limit gives the hazard function

$$
h_{i}(t)=\lim _{t^{\prime} \rightarrow t} \frac{1}{t^{\prime}-t} \frac{F_{i}\left(t^{\prime}\right)-F_{i}(t)}{1-F_{i}(t)}=\frac{f_{i}(t)}{G_{i}(t)} .
$$

This shows that the hazard function is a conditional density function, i.e. the density function divided by the survivor function. So, the hazard function allows for a local description of the development of a process. In order to calculate $h_{i}(t)$ we need information on the local probability density for events (exit from or entry into excessive deficits) at $t$, given by $f_{i}(t)$, and on the process up to $t$, given by $G_{i}(t)$.

Since $f_{i}(t)=-d G_{i}(t) / d t$, equation (10) is a differential equation in $t$ whose solution, subject to the initial condition $G_{i}(0)=1$. is

$$
G_{i}(t)=\exp \left(-\int_{0}^{t} h_{i}(u) d u\right)
$$

The relation between the hazard rate and the survivor function can also be expressed by 


$$
h_{i}(t)=-\frac{d \log G_{i}(t)}{d t}
$$

Thus, $h, f$, and $G$ are alternative ways of describing the distribution of the probability of exit from or entry into a state; if we know one, we can deduce the others.

Now, having defined the hazard functions for the states $s_{i}$, we have to evaluate the transition rates between the states and the effects of the relevant economic variables on these rates. The models $^{8}$ to be estimated can be specified as a Cox' proportional hazard with time-varying covariates:

$$
h_{i}\left(t, X_{i}, \alpha_{i}, \beta\right)=h_{o i}\left(t, \alpha_{i}\right) e^{X_{i}(t) \beta}
$$

where $h_{o i}(t, \alpha)$ is the baseline hazard function with parameter $\alpha_{i}$ and $X_{i}$ is a row-vector of covariates associated with the coefficients $\beta_{i}$.

If the baseline hazard function would be defined by a particular probability distribution that would have to be chosen a priori, our hazard model would be fully parametric. However, it is impossible to establish the shape of the hazard function $h_{i}$ for state changes into excessive and non-excessive deficits on any theoretical grounds. Therefore, in order to estimate the effects of the relevant economic variables on the hazard rates it is preferable to use the Cox model. Unlike the parametric hazard models, Cox's method does not require any specific choice of a particular probability distribution to represent the survival times. As a consequence, Cox's semi-parametric method is considerably more robust.

The initial approach proposed by Cox (1972) is commonly referred to as the proportional hazard model. That name is nevertheless misleading, because the model can be generalized to allow for non-proportional hazards, which is the case with our model. Given that this model incorporates time-dependent covariates ${ }^{9}$ which change at different rates for different countries, the hazard function can no longer be split in a time-dependent part and a time-invariant part. Therefore, the model is no longer proportional and the baseline hazard cannot be derived from the estimated

\footnotetext{
${ }^{8}$ Two models are estimated: one for the transition from excessive to non-excessive deficits, and one for the transition in the other direction.

${ }^{9}$ In this paper, time-variant regressors are introduced using the spell splitting technique. The model is estimated using partial likelihood procedures, taking into account all the censored and uncensored spells.
} 
Cox model. It is therefore necessary to estimate a parametric model in order to calculate the hazard function for the different constellations of covariates for the different countries. The most attractive specification for this is the complementary $\log$ - $\log$ function ${ }^{10}$ for grouped durations ${ }^{11}$ which provide identical estimates as the Cox model for the effects of the covariates on the hazard rate. To see this, lets begin with the equations 11 and 13 for the survivor and hazard functions for continuous time models. Given that we have annual data, we only observe whether or not an event ${ }^{12} \varepsilon_{i}$ occurred between time $t-1$ and $t$. This probability is one minus the probability of surviving ${ }^{13}$ beyond $t$ given survival up to $t-1$.

\section{Denote}

$$
E_{i}=\left\{\begin{array}{l}
1, \text { if the event } \varepsilon_{\mathrm{i}} \text { occurs } \\
0, \text { if the event } \varepsilon_{\mathrm{i}} \text { does not occur }
\end{array}\right.
$$

Given the observed history $H_{t-1}$ corresponding to the spell up to time $t-1$ in the follow-up, the conditional probability $P_{i}$ that the considered event occurs during the time interval $t-1$ and $t$ granted that no prior event $\varepsilon_{i}$ has occurred during the spell until $t-1$ can be expressed as

$$
P_{i}\left\{E_{i}(t)=1 \mid E_{i}=0 \text { during } H_{i, t-1}\right\}=1-G_{i}(t) / G_{i}(t-1)
$$

Using equations 11 and 13. we get

$$
P_{i}\left\{E_{i}(t)=1 \mid E_{i}(\tau)=0, \tau \in H_{i, t-1}\right\}=1-\exp \left\{-\int_{t-1}^{t}\left[h_{o i}(u) \longleftarrow \exp \left\{X_{i}(t) \beta\right\}\right] d u\right\}
$$

Next, by the grouped duration assumption, which implies that covariates $\mathrm{X}_{\mathrm{i}}(\mathrm{t})$ do change over time, but are fixed within the different time intervals $\{t-1 . t\}$, we have:

$$
P_{i}\left\{E_{i}(t)=1 \mid E_{i}(\tau)=0, \tau \in H_{i, t-1}\right\}=1-\exp \left\{-\exp \left\{X_{i}(t) \beta\right\} \int_{t-1}^{t} h_{o i}(u) d u\right\}
$$

\footnotetext{
${ }^{10}$ The complementary log-log function does not provide the continuous hazard rate, but, in our case, this is not a problem given that it does provide the conditional probabilities of entry and exits for time intervals. This information is sufficient for our analysis.

${ }^{11}$ Grouped duration data allows for exits or entries at any time, but given the discrete measurement process we only observe whether an exit or an entry have occurred in some time interval.

${ }^{12}$ We have two events: entry into or exit from excessive deficit.

${ }^{13}$ Given by the equations 6 and 11 .
} 
Since the baseline hazard $h_{o i}$ is unspecified, we can treat the integral of $h_{o i}$ as an unknown constant. Defining

$$
\lambda_{i}(t)=\log \int_{t-1}^{t} h_{o i}(u) d u
$$

we get the complementary log-log function

$$
P_{i}\left\{E_{i}(t)=1 \mid E_{i}(\tau)=0 \tau \in H_{i, t-1}\right\}=1-\exp \left[-\exp \left\{\lambda_{i}(t)+X_{i}(t) \beta\right\}\right]
$$

which provides estimates of $\beta_{i}$ that are identical to those of the Cox model for grouped data and at the same time we can derive estimates of the conditional probabilities $P_{i}$ for entries into and exits from excessive deficits.

\section{Data and empirical specifications}

For our analyses we used data obtained from the European Commission, on the budget deficits of the 15 countries that signed the Maastricht Treaty in $1992^{14}$, calculated as a percentage of their GDP over the period 1971-2007. ${ }^{15}$ Besides, we collected five economic covariates that were used as explanatory variables in the hazard function:

DEBTL Debt-to-GDP ratio, lagged by one year

EXPEND Government primary expenditure-to-GDP ratio

RECEIPT Government receipts-to-GDP ratio

GROWTH Growth rate

REALINL Real long-term interest rate, lagged by one year

In the literature on budget deficits, the definition of fiscal consolidation is not univocal. To consider the differences, Adam and Bevan (2003) present a useful categorisation of the existing work into two groups: (1) the level approach that ex ante defines a specific threshold and considers all countries that have a deficit smaller than this value consolidating; (2) the gradient

\footnotetext{
${ }^{14}$ These 15 countries are: Austria, Belgium, Denmark, Finland, France, Germany, Greece, Ireland, Italy, Luxemburg, The Netherlands, Portugal, Spain, Sweden and United Kingdom.

${ }^{15}$ For the last year, projections by the EC have been used. All data have been withdrawn from the AMECO database, the Macroeconomic Database of the EC.
} 
approach that evaluates the yearly change in the deficit, and regards all countries whose deficit decreases by more than a certain threshold to be in a period of consolidation. The latter approach certainly has it subtleties, and especially when a country is facing deficits far above the threshold level, it still allows for an evaluation of the policy of governments. However, given the explicit thresholds mentioned in the Stability and Growth Pact, together with the strict regulations and fines threatening countries that exceed the boundaries, especially the first approach is relevant in the current analysis.

Therefore, based on the data on budget deficits, and following the definition in the Stability and Growth Pact, we construct a dummy variable that attains the value 1 if country $i$ faces a budget deficit larger than three percent in year $t$ :

$$
E_{i}(t)=\left\{\begin{array}{c}
1, \text { if } \frac{\mathrm{Def}_{\mathrm{i}, \mathrm{t}}}{\mathrm{GDP}_{\mathrm{i}, \mathrm{t}}}>3 \% \\
0, \text { otherwise }
\end{array} .\right.
$$

This dummy variable is used for the analysis of entry dynamics; for the model for exit dynamics, we define a dummy variable that is based on exactly the same conditions, but reversed. This seems to be ambiguous, but by the asymmetry of the complementary log-log function, both the impacts of the covariates on two the different state variables and the estimated hazard rates may differ heavily between the two models.

The average budget deficit over all 15 countries and over the entire time period under consideration amounts 2.52 percent, with a standard deviation over the countries of 2.83 percent. Figure 1 displays the evolution of the budget deficits in the 15 countries together, revealing that an actual budget surplus is rare on average. The European deficit exceeded the three percent threshold from 1979 until 1997. with the exception of 1988 and 1989. Notable is the sharp decrease in deficits after the ratification of the Maastricht Treaty in 1993. carrying the average values from an all-time high $6.25 \%$ to an all-time low $-1.30 \%$. Although the recession following 9/11 caused an equally sharp incline, recent economic progress in the EU restrained that development after three years.

Table 1 presents an analysis of the budget deficits by evaluating the dummy variables that we have created. Over all the years, the countries faced excessive deficits 59 percent of the time. The average spell lasted 6.37 years, whereas the average spell of fiscal consolidation lasted 5.75 
years. The last for rows present the average probabilities of being in both states respectively with a break in 1994. following the ratification of the Maastricht Treaty. Due to the heavy influence of censoring on the durations in the smaller subintervals, we did not report on that variable in the table.

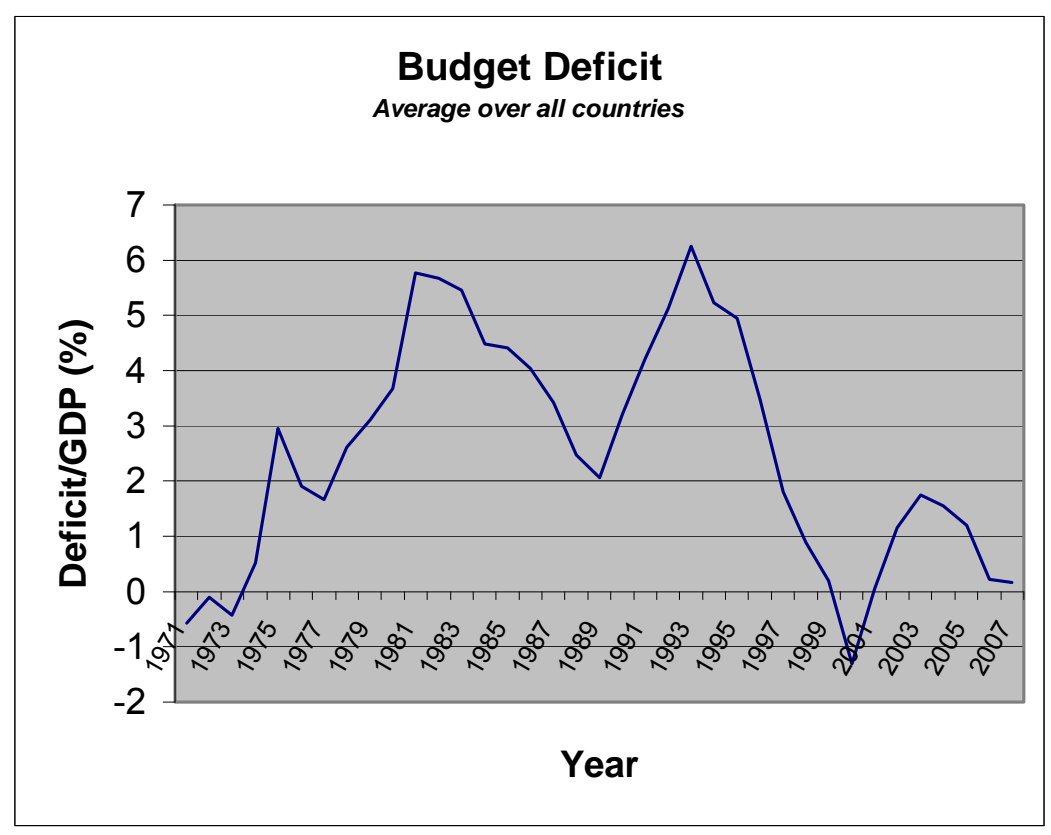

Figure 1: Average budget deficit in 15 countries under analysis

When evaluating the path of entry probabilities over time, we can see from figure 2 that at the periods when the average deficit was the highest, in 1981 and 1993.80 percent of the countries under consideration faced an excessive deficit. ${ }^{16}$ In line with the decrease in average deficit values after 1993. the probability of being in excessive deficit also declines, but it lasts until 1997 before the first signs of this development become clear. Apparently, although countries did start to work on fiscal consolidation, they were not able on average to meet the standards set in the Stability and Growth Pact during the first three years. The probabilities for 2007. based on predictions by the EC, are on average equal to the all-time low probabilities in 1999 and 2000.

In a survival analysis with a similar methodology as ours, but based on a shorter dataset, Bayar (2001) finds that receipts and expenditures are the covariates with the highest impact on the hazard rate, while the growth rate also plays a considerable role, especially in the model for exit dynamics. Figure 3 displays the time series of average government receipts-to GDP ratios and primary expenditure-to-GDP ratios for the 15 countries in our dataset. From this graph, we can

\footnotetext{
${ }^{16}$ Note that, by the reversed definition of the dummy variable when considering exit dynamics, these probabilities are simply 1 - the values reported in figure 2 .
} 
see that during both periods that showed sharp declines in the average deficits, 1981-1989 and 1993-200 1. expenditures were cut back whereas the receipts did not show a clear pattern. This suggests that governments primarily used their expenditures as an instrument to reduce their budget deficits. However, we need to evaluate the results from the probabilistic duration analyses in the next section in order to be able to draw any furthergoing conclusions on causality.

\begin{tabular}{|llcc|cc|}
\hline & & \multicolumn{2}{c|}{ Non-Exc. Def. } & \multicolumn{2}{c|}{ Excessive Deficit } \\
\hline \multirow{2}{*}{ All years } & Mean & 0.41 & 5.75 & 0.59 & 6.37 \\
& Pariance & 0.24 & 6.54 & 0.24 & 5.51 \\
\hline $\mathrm{T}<1994$ & Mean & 0.47 & & 0.53 & \\
& Variance & 0.25 & & 0.25 & \\
$\mathrm{~T} \geq 1994$ & Mean & 0.33 & & 0.67 & \\
& Variance & 0.22 & & 0.22 & \\
\hline
\end{tabular}

Table 1: Summary statistics for entry and exit dynamics into and from excessive deficit

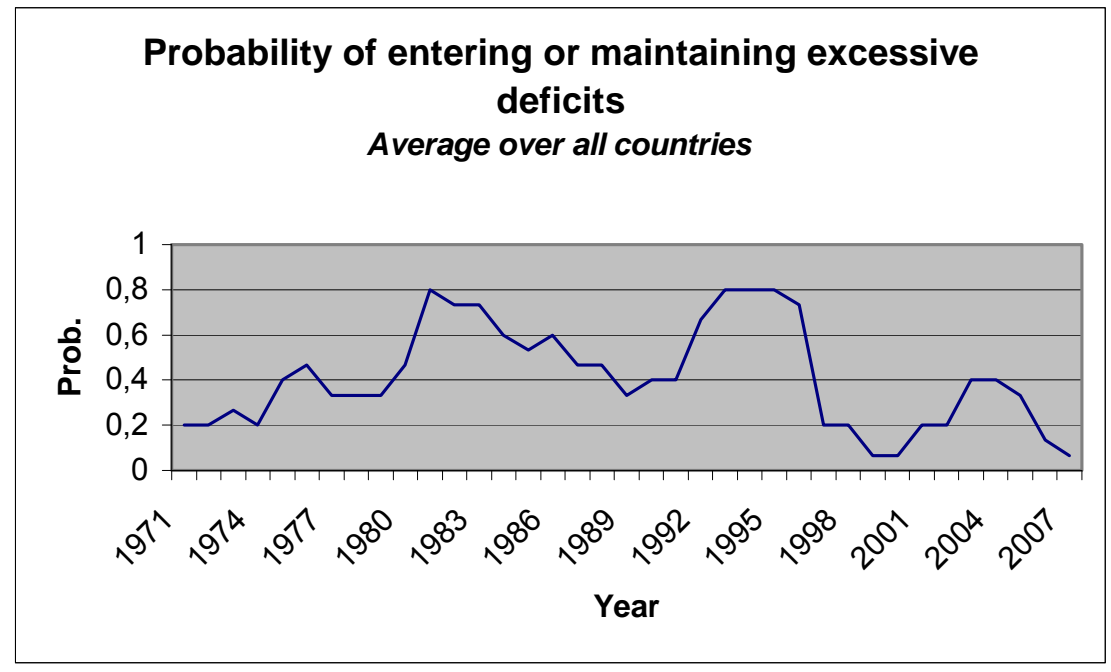

Figure 2: Average Probabilities of entering the state of excessive deficits over all countries

Average debt levels increased steadily from slightly under $30 \%$ during the 1970 to well over $70 \%$ on their peak in 1996. Afterwards, under pressure of the restrictions imposed by the Maastricht Treaty, fiscal consolidation led to an ongoing decrease in debt levels to a current level of 56 percent, a 20-year minimum. Growth rates initially show heavy fluctuations, along with the economic climate, but have been between 2 and 4.3 percent since 1993. 


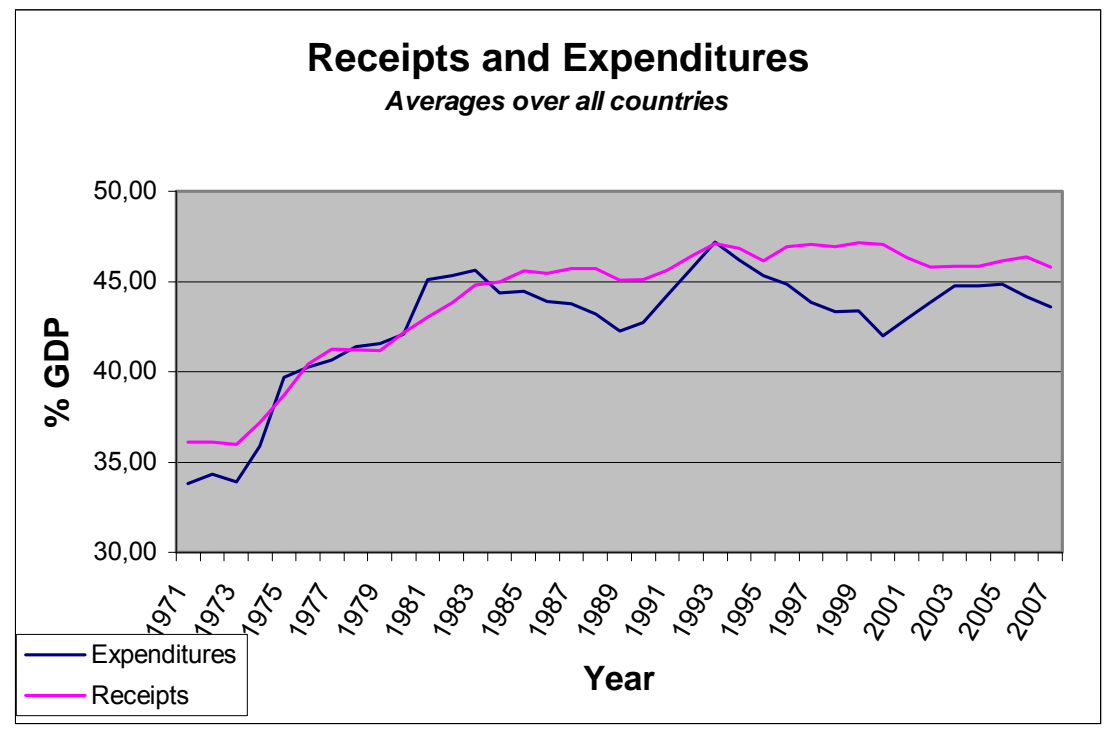

Figure 3: Average Government Receipts-to-GDP ratio and

Average Primary-Expenditures-to-GDP ratio for all 15 countries

\section{Empirical Framework}

As starting point for our analyses of entry dynamics, we use equation (18). Given the reversed definition used for creating the dummy variables for exit dynamics, we can use the same equation for these analyses, where only now the dependent variable $\mathrm{E}_{\mathrm{i}}(\mathrm{t})$ attains different values. As a basic model, we estimate equation (18) with one single constant over all countries by using maximum-likelihood techniques:

$$
P_{i}\left\{E_{i}(t)=1 \mid E_{i}(\tau)=0, \tau \in H_{i, t-1}\right\}=1-\exp \left[-\exp \left\{\lambda+X_{i}(t) \beta\right\}\right]
$$

This model specification, with a constant varying neither over time nor over the different countries, implies that we are treating the different observations as cross-section data. Although this model still allows for time-effects in the hazard rate, due to the explanatory power of the time-varying covariates, it ignores one important aspect of the data: heterogeneity due to dependency among observations within one country. However, it is implausible to assume that for a particular country, the different observations over time on the dummy variable are independent. Serial correlation in budget deficit values is one possible reason why observations dependency is likely to exist. However, there are plenty of other arguments. The stability of the government's budgetary policy is an important factor: when a country has experienced many years with excessive deficit, or when many attempts for fiscal consolidation have failed, one 
would expect the country to be more likely the country is to fall into excessive deficit again. Indeed, Illera and Mulas-Granados (2002) find that the number of failed fiscal consolidations in the past have a significantly positive impact on the probability of ending a period of fiscal consolidation again. Political stability in general can be regarded to play an important role: when the life of government's is short, and the political climate is chaotic, a productive long-term policy of fiscal consolidation is not likely. As a conclusion, there are many unobserved, countryspecific factors that are likely to cause dependence in the observations within a country.

Ignoring the presence of unobserved heterogeneity in our model would lead to a hazard rate that tends to decrease over time. Besides, the estimated coefficients would be attenuated towards zero (Allison, 1995). Therefore, in order to cope with the unobserved heterogeneity in our model, we include country-specific fixed effects in our analyses, by adding country-dummies in equation (19):

$P_{i}\left\{E_{i}(t)=1\left(E_{i}(\tau)=0 \tau \in H_{i, t-1}\right\}=1-\exp \left[-\exp \left\{\lambda+X_{i}(t) \beta+v_{i}\right\}\right]\right.$

We should carefully evaluate what the consequences are of the distributional assumptions that are imposed on the error term!

After estimating the parameter values of the different covariates, we use these estimates in order to calculate the implied hazard rate, conditional on the series of explanatory variables. Because these regressors differ per country and over time, we also obtain country-specific time-varying paths of hazard rates. As a test for the explanatory power of our model, we can compare the implicit probabilities of entry and exit from excessive deficit with the actual spells that countries went through.

\section{4: Results of analyses}

\section{4a. Empirical results for Model A}

Tables $1 \mathrm{a}$ and $1 \mathrm{~b}$ provide estimates for the basic model, which will be called model A, with only the five covariates included as explanatory variables in addition to the country- and timeinvariant constant $\lambda$ that represents the baseline part of the hazard function: 
$P_{i}\left(E_{i}(t)=1 \mid E_{i}(\tau)=0, \tau \in H_{i, t-1}\right)=1-\exp \left[-\exp \left\{\lambda+X_{i}(t) \beta\right\}\right]$.

The numerical values of the parameters reported in the tables cannot be interpreted straightforwardly, because they represent the effect of the covariates on the hazard rates via a complementary log-log link function. However, by applying a simple transformation, an intuitive interpretation of the results can be facilitated. The last column in the tables presents the percentage change in the hazard rate following a one unit increase in the covariate, where for e.g. the expenditures in the entry model in table 1a, we have:

$[\exp (0.963)-1] 100 \%=162.0 \%$

The likelihood-ratio chi-square statistics show that in both models, the global null hypothesis of insignificance of all variables is rejected, by comparing our model to a duration model without any explanatory variables. ${ }^{17}$ This implies that at least one of the covariates in our model possesses explanatory power. A test for significance of the individual explanatory variables is presented in the fourth column, from which we can draw the conclusion that, at a $5 \%$ level, in both models the constant is not significantly different from zero. Besides, in the model for entry dynamics, the growth rate is insignificant, whereas its positive impact on the hazard rate for exit dynamics is significant. All other covariates are highly significant as well, and the signs of their coefficients are in correspondence with our theoretical and intuitive expectations.

\begin{tabular}{|ccccr|}
\hline Entry & Coef. & Std. Err. & $\mathrm{P}>|\mathrm{z}|$ & Effect in \% \\
\hline$\lambda$ & -1.584 & 0.876 & 0.071 & \\
DEBTL & 0.060 & 0.006 & 0.000 & $6.2 \%$ \\
EXPEND & 0.963 & 0.094 & 0.000 & $162.0 \%$ \\
RECEIPT & -1.007 & 0.097 & 0.000 & $-63.5 \%$ \\
GROWTH & -0.085 & 0.055 & 0.124 & $-18.7 \%$ \\
REALINL & 0.172 & 0.039 & 0.000 & \\
& & & & \\
\hline & $\chi^{2}$ & 127.84 with 6 Degrees of Freedom, & $p$-value $=0.0000$ & \\
\hline
\end{tabular}

Table 1a: Estimates for Entries into excessive deficits under Model A

\begin{tabular}{|ccccr|}
\hline Exit & Coef. & Std. Err. & $\mathrm{P}>|\mathrm{z}|$ & Effect in \% \\
\hline$\lambda$ & -0.925 & 0.486 & 0.057 & \\
DEBTL & -0.035 & 0.004 & 0.000 & $-3.4 \%$ \\
EXPEND & -0.416 & 0.030 & 0.000 & $-34.0 \%$ \\
RECEIPT & 0.465 & 0.034 & 0.000 & $59.2 \%$ \\
GROWTH & 0.105 & 0.041 & 0.011 & $11.0 \%$ \\
REALINL & -0.097 & 0.028 & 0.001 & $-9.3 \%$ \\
& & & \\
\hline & $\chi^{2}$ & 248.16 with 6 Degrees of Freedom, & $p$-value $=0.0000$ & \\
\hline
\end{tabular}

\footnotetext{
${ }^{17}$ Therefore, the implicit global null hypothesis is: $H_{0}: \beta_{j}=0, \forall j$
} 
Table 1b: Estimates for Exits from excessive deficits under Model A

When evaluating the effect that the covariates have on the hazard rate, we observe that the government expenditures are the dominant factor for entering the state of excessive deficit. Government receipts have an important impact on both entry and exit rates and, in line with the findings in Bayar (2001), they play somewhat similar roles (in absolute terms) in the two models: a one unit increase in receipts increases the exit rate from excessive deficit by 59 percent, and at the same time decreases the entry risk by 64 percent. On the other hand, the effect of a one unit increase in the primary expenditures-to-GDP ratio is very asymmetrical between the two models: the exit rate decreases by 34 percent, whereas the entry probability increases by 162 percent. An important conclusion that can be drawn from these observations is that a government aiming at preventing the country from entering the state of excessive deficit should focus on controlling expenditures. On the other hand, once a country faces excessive deficit, an increase in receipts more effectively enhances the probability of exiting. Economic growth plays a rather limited role as potential instrument for policy makers. Not only does it turn insignificant in the model for entries, but its coefficient in the exit model is dominated by both expenditures and receipts. On the other hand, the lagged real interest rate is significant in both models, although its effect on the probabilities is rather limited.

Next to considering the effects of changes in the covariates isolated from each other, we should note here that simultaneous changes in the variables will have multiplicative effects: ceteris paribus, a simultaneous one-unit increase in primary expenditure-to-GDP ratio and a one-unit decrease in receipts will yield to an increase in the hazard for entry into excessive deficit of 617 percent:

$[\exp (0.963) \exp (1.007)-1] 100 \%=617 \%$

\section{4b.Correcting for unobserved heterogeneity: Including fixed effects}

After analysing the basic model, this section presents an extension by adding fixed effects $v_{\mathrm{i}}$ to the model. We will refer to this specification as Model B. Again, the equation for the analysis of exit dynamics is obtained by inversing the events of 'success' and 'failure'. 


\begin{tabular}{|c|c|c|c|c|c|}
\hline Entry & Coef, & Std,Err. & $\mathrm{P}>|\mathrm{z}|$ & Effect & \\
\hline$\lambda$ & 0.188 & 1.519 & 0.902 & & \\
\hline DEBTL & 0.087 & 0.012 & 0.000 & & $9.1 \%$ \\
\hline EXPEND & 1.264 & 0.136 & 0.000 & & $253.9 \%$ \\
\hline RECEIPT & -1.383 & 0.155 & 0.000 & & $-74.9 \%$ \\
\hline GROWTH & -0.102 & 0.063 & 0.104 & & \\
\hline REALINL & 0.255 & 0.052 & 0.000 & & $29.1 \%$ \\
\hline$v_{\mathrm{DK}} *$ & 2.190 & 0.980 & 0.025 & & \\
\hline$v_{\mathrm{GE}}$ & -0.542 & 0.663 & 0.414 & & \\
\hline$v_{\mathrm{GR}}$ & -0.736 & 0.626 & 0.240 & & \\
\hline$v_{\mathrm{SP}}$ & -0.445 & 0.745 & 0.550 & & \\
\hline$v_{\mathrm{FR}}$ & -0.763 & 0.733 & 0.298 & & \\
\hline$v_{\mathrm{IR}}$ & -0.543 & 0.730 & 0.457 & & \\
\hline$v_{\text {IT }}$ & -1.272 & 0.682 & 0.062 & & \\
\hline$v_{\mathrm{LU}}$ & 1.584 & 1.325 & 0.232 & & \\
\hline$v_{\mathrm{NL}}$ & 1.104 & 0.670 & 0.100 & & \\
\hline$v_{\mathrm{AU}}$ & 0.046 & 0.706 & 0.948 & & \\
\hline$v_{\mathrm{PT}}$ & 0.397 & 0.590 & 0.501 & & \\
\hline$v_{\mathrm{FI}}$ & 2.227 & 1.408 & 0.114 & & \\
\hline$v_{\mathrm{SE}}$ & 3.279 & 1.034 & 0.002 & & \\
\hline$v_{\mathrm{UK}}$ & -0.470 & 0.611 & 0.441 & & \\
\hline$\chi^{2}$ & 119.26 with 20 & Degrees of Freedom, & $p$-valu & 0.0000 & \\
\hline
\end{tabular}

Table 2a: Estimates for Entries into excessive deficits under Model B

*The subscripts are abbreviations for: Denmark (DK), Germany (GE), Greece (GR), Spain (SP), France (FR) Ireland (IR), Italy (IT), Luxembourg (LU), Netherlands (NL), Austria (AU), Portugal (PT), Finland (FI) Sweden (SE) and the UK (UK).

Tables $2 \mathrm{a}$ and $2 \mathrm{~b}$ report the estimation results of Model B. The log-likelihood chi-square statistics for both models indicate that the global null hypothesis can be rejected. At the same time, the parameters that were not significantly different from zero in Model A are insignificant in the new model as well: the constant terms in both models, and the growth rate for the entry dynamics possess no explanatory power. Next to that, almost all dummies that are included to capture the fixed effects turn out to be insignificant. However, that should not be a reason to ignore the unobserved heterogeneity in our observations, and the possibility of dependence among different observations over time within one country that can be a major cause of this heterogeneity. Since the number of spells in the dataset is limited, and the number of spells on which any particular fixed-effect dummy can be regressed is obviously constrained to the number of spells that a particular country faced, the explanatory power of almost all parameters $v_{\mathrm{i}}$ is insignificant. However, the influence of including fixed effects on the magnitude of the other, initial covariates is considerable. 


\begin{tabular}{|c|c|c|c|c|}
\hline Exit & Coef, & Std,Err. & $\mathrm{P}>|\mathrm{z}|$ & \\
\hline$\lambda$ & -0.231 & 1.420 & 0.871 & \\
\hline DEBTL & -0.054 & 0.009 & 0.000 & $-5.3 \%$ \\
\hline EXPEND & -0.755 & 0.072 & 0.000 & $-53.0 \%$ \\
\hline RECEIPT & 0.813 & 0.086 & 0.000 & $125.5 \%$ \\
\hline GROWTH & 0.123 & 0.055 & 0.026 & $13.1 \%$ \\
\hline REALINL & -0.151 & 0.039 & 0.000 & $-14.0 \%$ \\
\hline$v_{\mathrm{DK}}$ & -1.346 & 0.736 & 0.067 & \\
\hline$v_{\mathrm{GE}}$ & 0.433 & 0.579 & 0.455 & \\
\hline$v_{\mathrm{GR}}$ & -0.026 & 0.587 & 0.965 & \\
\hline$v_{\mathrm{SP}}$ & 0.188 & 0.575 & 0.744 & \\
\hline$v_{\mathrm{FR}}$ & 0.675 & 0.652 & 0.301 & \\
\hline$v_{\text {IR }}$ & 0.277 & 0.598 & 0.643 & \\
\hline$v_{\mathrm{IT}}$ & 0.555 & 0.622 & 0.373 & \\
\hline$v_{\mathrm{LU}}$ & -0.730 & 0.937 & 0.436 & \\
\hline$v_{\mathrm{NL}}$ & -0.411 & 0.589 & 0.486 & \\
\hline$v_{\mathrm{AU}}$ & 0.339 & 0.614 & 0.581 & \\
\hline$v_{\mathrm{PT}}$ & -3.474 & 0.814 & 0.000 & \\
\hline$v_{\mathrm{FI}}$ & -0.852 & 1.130 & 0.451 & \\
\hline$v_{\mathrm{SE}}$ & -1.961 & 0.936 & 0.036 & \\
\hline$v_{\mathrm{UK}}$ & -0.028 & 0.544 & 0.959 & \\
\hline$\chi^{2}$ & 158.00 with $20 \mathrm{I}$ & ees of Freedom, & $p$-value $=0.0000$ & \\
\hline
\end{tabular}

Table 2b: Estimates for Exits from excessive deficits under Model B

When comparing the parameter values of the economic explanatory variables in tables $2 \mathrm{a}-\mathrm{b}$ with the initial results under Model A, presented in table 1a-b, we can see that, except for the constant $\lambda$, all estimated parameters are more extreme. This is in line with our theoretical expectations, since ignoring unobserved heterogeneity tends to lead to estimated parameters being biased towards zero.

The more extreme magnitudes of the parameters are obviously also represented in the effects of a one-unit change of the covariates, reported in the last column. Again, the effects of a simultaneous change in variables add multiplicatively to the hazard rate, and in this case that yields rather extreme consequences: Considering a one-unit increase in the primary expenditures-to-GDP ratio and a one-unit decrease in receipts, the increase in the hazard rate amounts to 1311.2 percent. 


\section{4c. Is there a Maastricht-effect in the deficit dynamics?}

The conditions specified in the Maastricht Treaty, that later evolved into the Stability and Growth Pact, created considerable incentives for the participants to control their deficits, and to start pursuing a policy of fiscal consolidation. Therefore, intuitively one would indeed expect that a 'Maastricht-effect' could be observed, implying that after 1993. the risk of entering an excessive deficit declined and, more particularly, the probability of leaving that state increased. From a first analysis of the data in section 2. we saw that after reaching its all-time high level in 1993. the average deficit indeed started to decline soon afterwards. Accordingly the average dummy variable, representing the probability of being in excessive deficit, decreased as well, although this effect came with a lag of several years. Now, once we are able to determine the entry and exit probabilities endogenously, this also provides us with the opportunity to estimate whether indeed the hazard rates structurally changed after 1993. and if such a change can be detected, which magnitude it has.

\begin{tabular}{|c|c|c|c|c|}
\hline Entry & Coef. & Std. Err. & $\mathrm{P}>|\mathrm{z}|$ & \\
\hline$\lambda$ & -3.412 & 1.884 & 0.070 & \\
\hline DEBTL & 0.132 & 0.019 & 0.000 & $14.1 \%$ \\
\hline EXPEND & 1.558 & 0.185 & 0.000 & $374.9 \%$ \\
\hline RECEIPT & -1.646 & 0.204 & 0.000 & $-80.7 \%$ \\
\hline GROWTH & -0.159 & 0.080 & 0.047 & $-14.7 \%$ \\
\hline REALINL & 0.150 & 0.060 & 0.012 & $16.2 \%$ \\
\hline$v_{\mathrm{DK}}$ & 3.450 & 1.243 & 0.005 & \\
\hline$v_{\mathrm{GE}}$ & 1.211 & 0.911 & 0.184 & \\
\hline$v_{\mathrm{GR}}$ & 0.519 & 0.796 & 0.514 & \\
\hline$v_{\mathrm{SP}}$ & 1.031 & 0.914 & 0.259 & \\
\hline$v_{\mathrm{FR}}$ & 0.999 & 1.030 & 0.332 & \\
\hline$v_{\mathrm{IR}}$ & -0.224 & 0.882 & 0.799 & \\
\hline$v_{\text {IT }}$ & -0.386 & 0.893 & 0.665 & \\
\hline$v_{\mathrm{LU}}$ & 3.914 & 1.712 & 0.022 & \\
\hline$v_{\mathrm{NL}}$ & 1.946 & 0.915 & 0.034 & \\
\hline$v_{\mathrm{AU}}$ & 0.905 & 0.955 & 0.344 & \\
\hline$v_{\mathrm{PT}}$ & 2.661 & 0.916 & 0.004 & \\
\hline$v_{\mathrm{FI}}$ & 3.693 & 1.804 & 0.041 & \\
\hline$v_{\mathrm{SE}}$ & 3.684 & 1.281 & 0.004 & \\
\hline$v_{\mathrm{UK}}$ & -0.264 & 0.774 & 0.733 & \\
\hline$\delta_{\text {Maastricht }}$ & -0.894 & 0.450 & 0.047 & \\
\hline$\delta_{\text {Euro }}$ & -3.215 & 0.611 & 0.000 & \\
\hline & 92.30 & es of Fr & $p$-value & \\
\hline
\end{tabular}

Table 3a: Estimates for Entries into excessive deficits under Model C 
After the enforcement of the Maastricht Treaty, a next step on the path towards European integration was the introduction of the Euro. Since the rules and regulations related to both institutional changes are quite different, we distinguish between them and estimate their impacts separately. ${ }^{18}$ In order to measure both effects, we capture the implementation of the Maastricht Treaty and the introduction of the Euro by including temporal dummy variables in the analyses, lasting from 1994-1998 $\left(\delta_{\text {Maastricht }}\right)$ and starting from $1999\left(\delta_{\text {Euro }}\right)$ respectively:

$$
P_{i}\left(E_{i}(t)=1 \mid E_{i}(\tau)=0, \tau \in H_{i, t-1}\right)=1-\exp \left[-\exp \left\{\lambda+X_{i}(t) \beta+v_{i}+\delta_{M}(t)+\delta_{E}(t)\right\}\right]
$$

The results are presented in tables $3 a-b$, and a first study of the results shows that, next to global significance of the model by rejection of the global null, also the two particular dummy variables are significant in both models.

\begin{tabular}{|c|c|c|c|c|}
\hline Exit & Coef. & Std. Err. & $\mathrm{P}>|\mathrm{z}|$ & \\
\hline$\lambda$ & -0.127 & 1.483 & 0.932 & \\
\hline DEBTL & -0.091 & 0.014 & 0.000 & $-8.7 \%$ \\
\hline EXPEND & -0.802 & 0.081 & 0.000 & $-55.2 \%$ \\
\hline RECEIPT & 0.903 & 0.102 & 0.000 & $146.7 \%$ \\
\hline GROWTH & 0.164 & 0.058 & 0.005 & $17.8 \%$ \\
\hline REALINL & -0.085 & 0.044 & 0.053 & \\
\hline$v_{\mathrm{DK}}$ & -2.382 & 0.917 & 0.009 & \\
\hline$v_{\mathrm{GE}}$ & -0.947 & 0.747 & 0.205 & \\
\hline$v_{\mathrm{GR}}$ & -0.298 & 0.695 & 0.667 & \\
\hline$v_{\mathrm{SP}}$ & -0.667 & 0.729 & 0.360 & \\
\hline$v_{\mathrm{FR}}$ & -1.138 & 0.827 & 0.169 & \\
\hline$v_{\text {IR }}$ & 0.703 & 0.719 & 0.328 & \\
\hline$v_{\text {IT }}$ & 0.587 & 0.749 & 0.434 & \\
\hline$v_{\mathrm{LU}}$ & -2.808 & 1.184 & 0.018 & \\
\hline$v_{\mathrm{NL}}$ & -1.449 & 0.754 & 0.055 & \\
\hline$v_{\mathrm{AU}}$ & -0.985 & 0.796 & 0.216 & \\
\hline$v_{\text {РT }}$ & -4.059 & 0.951 & 0.000 & \\
\hline$v_{\mathrm{FI}}$ & -2.902 & 1.366 & 0.034 & \\
\hline$v_{\mathrm{SE}}$ & -3.183 & 1.096 & 0.004 & \\
\hline$v_{\mathrm{UK}}$ & -0.409 & 0.672 & 0.543 & \\
\hline$\delta_{\text {Maastricht }}$ & 0.925 & 0.365 & 0.011 & \\
\hline$\delta_{\text {Euro }}$ & 2.217 & 0.451 & 0.000 & \\
\hline
\end{tabular}

Table 3b: Estimates for Exits from excessive deficits under Model $\mathrm{C}$

\footnotetext{
${ }^{18}$ One should note that the convergence criteria, imposed on the members of the EU by the ratification of the Maastricht Treaty, were still in force after 1998. but in our model, from this date on they are captured by the dummy on the introduction of the Euro.
} 
In line with our expectations, both the ratification of the Maastricht Treaty, leading to the implementation of the convergence criteria for candidate countries for the Economic and Monetary Union, and the introduction of the Euro led to a decrease in the risk to enter excessive deficits, whereas the probability of exiting once a country faced excessive deficits has increased. Both effects are significant in both models. The constants in our models are still insignificant, but the growth rate now fulfils an explanatory role in both models. By adding the two dummy variables, we also observe a change in the impact of the real interest rate: in the model for entry dynamics, a one-unit increase leads to a smaller increase in the hazard rate, whereas in the exit model, the variable even turns slightly insignificant. The effects of the other explanatory variables increase, which could be an indication that the additional control variables capture more of the variability of our dependent variable, that would usually be accounted for by lower estimates for our initial economic covariates.

\section{4d. Did the Maastricht effect cause structural changes in the parameters?}

Including dummy variables is one way to deal with temporal dynamics in the model. In the previous subsection, it allowed us to evaluate whether the probabilities of entry and exit changed following collective institutional changes. However, as a more rigorous alternative one could also consider whether the explanatory power of the covariates changed after the ratification of the Maastricht Treaty. Tables 4a-b show estimations of our basic model A, but this time allowing for a structural break in the parameters in 1994. the year that the convergence criteria from the Maastricht Treaty went into force. From this analysis, various conclusions can be drawn, that to a great extent also explain notions from our previously considered models, and besides explain observed differences between our current analyses and earlier results (Bayar, 2001).

Starting from the observation that global insignificance can be rejected, tables $4 \mathrm{a}-\mathrm{b}$ show that variables that exhibited weak explanatory power in some or all of the previous tables, are now more powerful in at least one of the two periods under consideration. In the model for entry dynamics, the growth rate is highly insignificant in the second period, but has indicative explanatory power in the first interval 1970-1993. Contrarily, the real interest rate has a high impact on the hazard rate, but only in the period after the implementation of the Maastricht Treaty. For the more robust covariates, we also observe considerable differences between the two periods, where especially the effect of the primary expenditures-to-GDP ratio increases sharply in the second period. For the lagged debt-to-GDP ratio, the difference between the periods is smaller, whereas the constant is significant only in the first period. 
In the model for exit dynamics, the growth rate is also significant in the first period only, while the real interest rate turns significant only after 1993. One striking difference with the results of model A without breaks is the sharp increase in the effect of receipts in the post-Maastricht era. After the break, countries that want to prevent themselves from having an excessive deficit minimise this risk by focusing on controlling their expenditures, following table $4 \mathrm{a}$, whereas countries that are in excessive deficit should focus on the receipts. It is interesting to note that after 1993. the majority of countries were in excessive deficit, and tried to clean up their sheets by cutting back their expenditures. However, our model suggests that, especially in this second period, an increase in receipts would be indicatively more effective when trying to maximise the probability of exiting.

\begin{tabular}{|c|c|c|c|c|c|c|c|c|}
\hline \multirow[t]{2}{*}{ Entry } & \multicolumn{2}{|c|}{ Coef, } & \multicolumn{2}{|c|}{ Std, } & \multicolumn{2}{|c|}{$\mathrm{P}>|\mathrm{z}|$} & \multicolumn{2}{|c|}{ Effect } \\
\hline & Per $_{1}$ & $\mathrm{Per}_{2}$ & Per $_{1}$ & $\mathrm{Per}_{2}$ & $\operatorname{Per}_{1}$ & $\mathrm{Per}_{2}$ & Per $_{1}$ & $\mathrm{Per}_{2}$ \\
\hline$\lambda$ & -3.382 & -3.359 & 1.127 & 2.434 & 0.003 & 0.168 & & \\
\hline DEBTL & 0.080 & 0.087 & 0.011 & 0.015 & 0.000 & 0.000 & $8.4 \%$ & $9.1 \%$ \\
\hline EXPEND & 0.947 & 1.349 & 0.126 & 0.235 & 0.000 & 0.000 & $157.7 \%$ & $285.3 \%$ \\
\hline RECEIPT & -0.950 & -1.427 & 0.127 & 0.236 & 0.000 & 0.000 & $-61.3 \%$ & $-76.0 \%$ \\
\hline GROWTH & -0.152 & 0.035 & 0.073 & 0.105 & 0.036 & 0.738 & $-14.1 \%$ & \\
\hline REALINL & 0.039 & 0.495 & 0.049 & 0.102 & 0.429 & 0.000 & & $64.1 \%$ \\
\hline & $\chi^{2}$ & 113.16 & $12 \mathrm{De}$ & $s$ of Fre & $p$ - v & $=0.0000$ & & \\
\hline
\end{tabular}

Table 4a: Estimates for Entries into excessive deficits under Model A with one structural break in 1994

\begin{tabular}{|cccccllll|}
\hline Entry & \multicolumn{2}{c}{ Coef, } & \multicolumn{2}{c}{ Std, } & \multicolumn{2}{c|}{$\mathrm{P}>|\mathrm{z}|$} & \multicolumn{2}{c|}{ Effect } \\
\hline & $\mathrm{Per}_{1}$ & $\mathrm{Per}_{2}$ & $\mathrm{Per}_{1}$ & $\mathrm{Per}_{2}$ & $\mathrm{Per}_{1}$ & $\mathrm{Per}_{2}$ & $\mathrm{Per}_{1}$ & $\mathrm{Per}_{2}$ \\
$\lambda$ & -0.312 & 3.514 & 0.630 & 1.900 & 0.621 & 0.064 & & \\
DEBTL & -0.059 & -0.081 & 0.008 & 0.015 & 0.000 & 0.000 & $-5.7 \%$ & $-7.8 \%$ \\
EXPEND & -0.369 & -1.188 & 0.038 & 0.209 & 0.000 & 0.000 & $-30.9 \%$ & $-69.5 \%$ \\
RECEIPT & 0.417 & 1.235 & 0.044 & 0.207 & 0.000 & 0.000 & $51.7 \%$ & $243.8 \%$ \\
GROWTH & 0.145 & -0.022 & 0.053 & 0.122 & 0.006 & 0.857 & $15.6 \%$ & \\
REALINL & -0.035 & -0.515 & 0.035 & 0.133 & 0.314 & 0.000 & & $-40.3 \%$ \\
& & & & & & & \\
\hline
\end{tabular}

Table 4b: Estimates for Exits from excessive deficits under Model A, with one structural break in 1994 


\section{4e. Allowing for a structural break and capturing heterogeneity}

In correspondence with our earlier extension of the basic model, by adding fixed effects to the basic model formulation, in this case a similar extension is used in order to capture unobserved heterogeneity in the model. The model in the previous subsection is expanded by adding both country-specific fixed effects and a temporal dummy variable for the introduction of the Euro. Although the overall null hypothesis can certainly be rejected, the fixed effect parameters are to a large extent insignificant, except for Denmark, Portugal and Sweden. This insignificance can be explained by the fact that the number of spells in the dataset is to small for including such a large number of explanatory variables. However, inclusion of these fixed effects does indicatively improve the explanatory power of our model, when evaluated by comparing the predicted pattern of hazard rates with the actual path of excessive and non-excessive deficits per country, as will be outlined in the next section.

\begin{tabular}{|c|c|c|c|c|c|c|c|c|}
\hline \multirow[t]{2}{*}{ Entry } & \multicolumn{2}{|c|}{ Coef. } & \multicolumn{2}{|c|}{ Std. Err. } & \multicolumn{2}{|c|}{$\mathrm{P}>|\mathrm{z}|$} & \multicolumn{2}{|c|}{ Effect } \\
\hline & $\mathrm{Per}_{1}$ & $\mathrm{Per}_{2}$ & $\mathrm{Per}_{1}$ & $\mathrm{Per}_{2}$ & $\mathrm{Per}_{1}$ & $\mathrm{Per}_{2}$ & $\mathrm{Per}_{1}$ & $\mathrm{Per}_{2}$ \\
\hline$\lambda$ & -4.313 & -4.683 & 2.140 & 4.575 & 0.044 & 0.306 & & \\
\hline DEBTL & 0.120 & 0.148 & 0.022 & 0.030 & 0.000 & 0.000 & $12.8 \%$ & $15.9 \%$ \\
\hline EXPEND & 1.371 & 2.144 & 0.205 & 0.433 & 0.000 & 0.000 & $293.9 \%$ & $753.4 \%$ \\
\hline RECEIPT & -1.415 & -2.254 & 0.231 & 0.414 & 0.000 & 0.000 & $-75.7 \%$ & $-89.5 \%$ \\
\hline GROWTH & -0.131 & -0.073 & 0.093 & 0.179 & 0.159 & 0.684 & & \\
\hline REALINL & 0.103 & 0.478 & 0.063 & 0.205 & 0.105 & 0.02 & & $61.2 \%$ \\
\hline$v_{\mathrm{DK}}$ & 2.953 & & 1.462 & & 0.043 & & & \\
\hline$v_{\mathrm{GE}}$ & 0.443 & & 1.017 & & 0.663 & & & \\
\hline$v_{\mathrm{GR}}$ & 0.785 & & 1.046 & & 0.453 & & & \\
\hline$v_{\mathrm{SP}}$ & 0.719 & & 0.950 & & 0.449 & & & \\
\hline$v_{\mathrm{FR}}$ & 0.324 & & 1.205 & & 0.788 & & & \\
\hline$v_{\mathrm{IR}}$ & -0.498 & & 1.003 & & 0.619 & & & \\
\hline$v_{\text {IT }}$ & 0.008 & & 1.243 & & 0.995 & & & \\
\hline$v_{\mathrm{LU}}$ & 3.059 & & 1.825 & & 0.094 & & & \\
\hline$v_{\mathrm{NL}}$ & 1.316 & & 1.054 & & 0.212 & & & \\
\hline$v_{\mathrm{AU}}$ & 0.349 & & 1.073 & & 0.745 & & & \\
\hline$v_{\mathrm{PT}}$ & 2.546 & & 0.991 & & 0.010 & & & \\
\hline$v_{\mathrm{FI}}$ & 3.093 & & 2.057 & & 0.133 & & & \\
\hline$v_{\mathrm{SE}}$ & 3.565 & & 1.646 & & 0.030 & & & \\
\hline$v_{\mathrm{UK}}$ & -0.467 & & 0.870 & & 0.592 & & & \\
\hline$\delta_{\text {Euro }}$ & -2.336 & & 0.817 & & 0.004 & & & \\
\hline & $x^{2}$ & 7.51 wit & 7 Degree & f Freec & $p$-va & $e=0.00$ & & \\
\hline
\end{tabular}

Table 5a: Estimates for Entries into excessive deficits under Model $C$ with one structural break in 1994 
Table 5a shows that the introduction of the Euro had a strongly negative effect on the risk of entering the state of excessive deficits, whereas this effect is smaller and insignificant at a 95 percent level when considering exit probabilities. Most parameters estimates are more extreme than the values found in the model without fixed effects, which is consistent with our earlier findings in the model without a break.

\begin{tabular}{|c|c|c|c|c|c|c|c|c|}
\hline \multirow[t]{2}{*}{ Exit } & \multicolumn{2}{|c|}{ Coef. } & \multicolumn{2}{|c|}{ Std. Err. } & \multicolumn{2}{|c|}{$\mathrm{P}>|\mathrm{z}|$} & \multicolumn{2}{|c|}{ Effect } \\
\hline & $\mathrm{Per}_{1}$ & $\mathrm{Per}_{2}$ & $\mathrm{Per}_{1}$ & $\mathrm{Per}_{2}$ & $\mathrm{Per}_{1}$ & $\mathrm{Per}_{2}$ & $\mathrm{Per}_{1}$ & $\mathrm{Per}_{2}$ \\
\hline$\lambda$ & 0.823 & 3.912 & 1.679 & 3.133 & 0.624 & 0.212 & & \\
\hline DEBTL & -0.079 & -0.123 & 0.014 & 0.026 & 0.000 & 0.000 & $-7.6 \%$ & $-11.6 \%$ \\
\hline EXPEND & -0.694 & -1.520 & 0.084 & 0.286 & 0.000 & 0.000 & $-50.0 \%$ & $-78.1 \%$ \\
\hline RECEIPT & 0.752 & 1.607 & 0.108 & 0.285 & 0.000 & 0.000 & $112.2 \%$ & $398.9 \%$ \\
\hline GROWTH & 0.129 & 0.103 & 0.063 & 0.160 & 0.042 & 0.522 & $13.8 \%$ & \\
\hline REALINL & -0.061 & -0.470 & 0.046 & 0.196 & 0.178 & 0.017 & & $-37.5 \%$ \\
\hline$v_{\mathrm{DK}}$ & -1.664 & & 1.023 & & 0.104 & & & \\
\hline$v_{\mathrm{GE}}$ & -0.309 & & 0.802 & & 0.700 & & & \\
\hline$v_{\mathrm{GR}}$ & -0.625 & & 0.809 & & 0.440 & & & \\
\hline$v_{\mathrm{SP}}$ & -0.404 & & 0.774 & & 0.601 & & & \\
\hline$v_{\mathrm{FR}}$ & -0.316 & & 0.898 & & 0.725 & & & \\
\hline$v_{\text {IR }}$ & 0.729 & & 0.774 & & 0.347 & & & \\
\hline$v_{\text {IT }}$ & 0.507 & & 0.909 & & 0.577 & & & \\
\hline$v_{\mathrm{LU}}$ & -1.950 & & 1.216 & & 0.109 & & & \\
\hline$v_{\mathrm{NL}}$ & -1.019 & & 0.827 & & 0.218 & & & \\
\hline$v_{\mathrm{AU}}$ & -0.340 & & 0.859 & & 0.692 & & & \\
\hline$v_{\mathrm{PT}}$ & -3.412 & & 0.970 & & 0.000 & & & \\
\hline$v_{\mathrm{FI}}$ & -2.101 & & 1.509 & & 0.164 & & & \\
\hline$v_{\mathrm{SE}}$ & -2.579 & & 1.276 & & 0.043 & & & \\
\hline$v_{\mathrm{UK}}$ & -0.423 & & 0.777 & & 0.586 & & & \\
\hline$\delta_{\text {Euro }}$ & 1.165 & & 0.605 & & 0.054 & & & \\
\hline
\end{tabular}

Table 5b: Estimates for Exits from excessive deficits under Model $C$, with one structural break in the parameters in 1994

Although the results for the models with a break can be compared to the actual policies implemented by the government, as a tool to measure their effectiveness, the implications of the indicative differences between the two periods cannot be derived straightforwardly. When using the results as an indicator for future, out-of-sample policy, an obvious conclusion would be that the roles of different covariates have changed over time. New policy should therefore be based on the results over the most recent period, of which the considerations in the previous paragraph are a clear example. However, when considering the in-sample dynamics of the different covariates a posteriori, it is harder to draw clear-cut conclusions: although it is clear that the 
impact of e.g. the expenditures-to-GDP ratio has risen, does that describe a change in the behaviour of governments (i.e. did they more intensively use the expenditures as an instrument for fiscal consolidation, such that a change in this variable is now stronger associated with budgetary improvement)? Or is it rather an indication of foregone opportunities for countries that performed badly in the second period (i.e. some (economic) force caused the expenditures to become more important, and countries that did not make use of this consequently performed worse)? Besides, does the increase in the magnitude of the impacts of all covariates except for the growth rate indicate that governments are under a higher pressure to use the correct measures to combat excessive deficits (i.e. has there been an increase in the volatility of the hazard rates, caused by larger impacts, such that the consequences of any choice regarding the fiscal policy are more extreme)? Or did the convergence in policies among the member states of the EU cause an increase in effectiveness of (almost all) the different instruments?

In order to answer these questions, an analysis of the forces behind the changed dynamics is needed, by analysing more country-specific institutional variables and by closer consideration of the dynamics of the hazard rates over time on an individual basis. In part, that goes beyond the scope of this paper. However, in the next section we will present an analysis of time-series of implied hazard on a country-per-country basis.

\section{Implied Hazard Rates}

Conditioning on the parameter estimates that were considered in the previous section, one can calculate the implied hazard rates by simply substituting the estimated values for the parameters $\lambda$ and $\beta$ in the estimation equation, and forecasting the dependent variable by using the actual values of the covariates. Irrespective of whether the model specification allows for a break in these parameters or not, the transition rates from the origin state $j$ to the destination state $k$ vary with different constellations of covariates, over countries and over time. In other words, the transition rates are country and time specific.

The averages of the hazard rates over the different time periods under consideration are presented per country in table 6 . Besides, this table presents the current transition probabilities in 2006. and an average of the hazards conditioning on the state in which the country actually found itself; we can see that e.g. Austria, when facing an excessive deficit, had a probability of leaving this state of 33 percent, on average, whereas the country, when having a non-excessive deficit (or a surplus), faced a risk of 10.7 percent to switch to the state of excessive deficits the next year. 
The evolution of the hazard rates per country over time is presented more specifically in the appendix. There, the implied entry risks and exit probabilities are plotted together with the actual path of the dependent variable 'Excess', the dummy variable denoting 1 if a country is in excessive deficit and 0 otherwise.

\begin{tabular}{|lrrrrrrrr|}
\hline & \multicolumn{1}{c}{$1971-1993$} & \multicolumn{2}{c}{$1994-2006$} & \multicolumn{2}{c}{2006} & \multicolumn{2}{c|}{ Split States } \\
& \multicolumn{1}{r}{ Entry } & \multicolumn{1}{c}{ Exit } & \multicolumn{1}{c}{ Entry } & \multicolumn{1}{c}{ Exit } & \multicolumn{1}{l}{ Entry } & \multicolumn{1}{l}{ Exit } & \multicolumn{1}{c}{ Entry } & \multicolumn{1}{c}{ Exit } \\
\hline Austria & 34.5 & 70.7 & 28.3 & 71.9 & 0.4 & 100.0 & 10.7 & 33.0 \\
Belgium & 95.1 & 10.4 & 26.9 & 69.1 & 0.1 & 100.0 & 6.7 & 7.7 \\
Denmark & 21.6 & 78.8 & 8.5 & 92.7 & 0.0 & 100.0 & 5.4 & 31.3 \\
Finland & 9.5 & 90.5 & 22.8 & 79.8 & 0.0 & 100.0 & 0.8 & 9.3 \\
France & 14.5 & 88.2 & 45.0 & 55.2 & 13.5 & 82.6 & 9.8 & 32.8 \\
Germany & 25.0 & 77.9 & 51.8 & 51.8 & 7.0 & 92.0 & 15.3 & 38.0 \\
Greece & 60.1 & 36.4 & 74.9 & 19.8 & 74.2 & 20.1 & 19.2 & 10.1 \\
Ireland & 77.7 & 22.4 & 2.0 & 98.1 & 0.0 & 100.0 & 9.6 & 14.7 \\
Italy & 10.0 & 4.0 & 60.3 & 37.6 & 100.0 & 2.5 & 16.3 & 6.0 \\
Luxembourg & 5.1 & 96.8 & 0.0 & 100.0 & 0.0 & 100.0 & 0.9 & 45.5 \\
Netherlands & 57.6 & 45.0 & 16.2 & 85.3 & 0.0 & 100.0 & 11.3 & 24.0 \\
Portugal & 70.9 & 12.5 & 80.5 & 7.7 & 100.0 & 1.3 & 27.6 & 5.6 \\
Spain & 46.4 & 57.3 & 36.8 & 66.6 & 0.0 & 100.0 & 7.1 & 16.9 \\
Sweden & 30.2 & 71.2 & 22.6 & 78.1 & 0.1 & 100.0 & 5.4 & 18.2 \\
UK & 63.3 & 35.2 & 35.4 & 64.7 & 31.6 & 62.9 & 15.4 & 18.6 \\
\hline
\end{tabular}

Table 6: average hazard rates per country

As a common pattern in all graphs, a sharp increase in exit probabilities is observable in the second half of the 1990s, that comes together with a sharp decrease in entry probabilities. This came after a period of three years, 1993-1995. during which only three countries in our set did not face excessive deficits. Although the 'Maastricht effect' in our previous analyses was the strongest when measured starting from 1994. we can see that for most countries, the actual improvement in terms of decreasing entry risks and increasing exit probabilities comes with a lag of two or three years.

As an exception, we see that Portugal did not experience a sharp increase in exit probabilities. However, still the country faced a period of non-excessive deficits, following a slight increase in exit rates together with a strongly declining entry risk. Nevertheless, after a total of four years of having deficits slightly below three percent between 1999 and 2003. with a minimum of 2.7. Portugal seems to have returned to a state of long-lasting excessive deficits, with very high entry risks and a very low probability of exiting. 
Like Portugal, also Greece and Italy have historically been vulnerable to budget deficits, with both countries facing an excessive deficit in a record 84 and 68 percent of the time, respectively. Although both countries did experience a sharp increase in the exit rates together with a sharp decrease in the risk of entering the state of excessive deficit at the end of the 1990s, the evolution of these probabilities shows a similar pattern to Portugal's, with a rather quick return to the state of excessive deficits combined with a low probability of leaving that state. For Greece, the short period of improvement in probabilities did not even lead to an escape from excessive deficits until recently the country managed to cut back its deficit below the threshold.

On the other hand, Belgium and Ireland, traditionally also facing long spells of excessive deficits, managed to structurally improve their situations. After 1996. Belgium's deficit did not exceed 2.3 percent, and during five years it even faced a budget surplus. Ireland, facing deficits of over 10 percent in the first half of the 1980s, consolidated its accounts as of 1988. and despite a slight deterioration in the probabilities, it did not face an excessive deficit afterwards. After 1996. all years except for 2002 showed a budget surplus for Ireland, with entry and exit rates consistently supporting this favourable situation.

After the jointly successful period of fiscal consolidation in the 1990s, France, Germany and the UK experienced deterioration in their situations, with the former two re-entering the state of excessive deficit in 200 2. and the latter one in 2003. For the first time since the introduction of the Stability and Growth Pact, the majority of countries in the EU faced a recession, and it lasted three years before France and the UK were able to cut back their deficits. Germany, traditionally facing volatile entry and exit probabilities, needed one more year to leave the state excessive deficit that is ruled out by the Stability Pact.

The Netherlands faced a more temporary deterioration early in the new century, with a simultaneous decrease in the exit rate and a slight increase in the entry rate. Whereas comparable developments did not lead to state changes for Sweden and Belgium, the Netherlands faced one year of excessive deficit in 2003.

Austria, Denmark, Finland and Spain managed to keep their entry risks very low after the period of improvement during the 1990s. Whereas Austria and Spain used to have more and longer spells of excessive deficits before, Finland only exceeded the threshold between 1992 and 1996. With the exception of 1993 and 1994. Denmark did not cross this border since 1984. facing correspondingly low probabilities of entry and high exit rates. 
Finally, Luxembourg has faced the most beneficial situation: in only 6 years out of the 36 in our dataset, the country actually faced a deficit, and only in 198 1. this deficit was larger than 3 percent. Apart from the change in probabilities that is observable in the same year, the country did not face entry rates larger than 0.09 . or exit rates smaller than 0.91 .

\section{Conclusion}

The emergence and persistence of large public deficits and debt in many industrial countries during the last decades has generated a widespread concern that discretion in policy making may lead to excessive deficits. Fiscal discipline has been one of the most debated issues in recent years, and in Europe the discussion focussed particularly on consequences of the ratification of the Maastricht Treaty and the implementation of the Stability and Growth Pact. Whereas the success of fiscal consolidation and the factors facilitating this, have been investigated in considerable detail, so far very little attention has been paid to the dynamics of excessive deficits. This paper is an attempt to contribute to our understanding of the economic determinants of budgetary dynamics. The following conclusions emerge from the study:

- Government receipts play a capital role in the exits, whereas for the entries into excessive deficits the dominant role is played by the primary expenditures. This implies that even if government receipts play a major role in exiting, fiscal policy should then take over and keep a strong control over expenditures to secure a lasting budgetary consolidation.

- In the monetary union the focus should be on the expenditure consolidation side in order to prevent any entry into excessive deficits.

- Small but simultaneous changes in the economic situation and government policy may induce important changes in the state of public finances.

- Even if all the Member States with the exception of Italy and Portugal are now in a nonexcessive deficit situation, especially Greece certainly faces a great risk of re-entering this state, and several other countries (France, Germany, and the UK) only recently showed an improvement in terms of a reduction of the entry risk and a simultaneous increase in the exit rate. 
- Both major institutional changes that affected the member states of the European Union turned out to have a significantly positive effect on the odds for the members to pursue a successful and consolidating budget policy. The ratification of the Maastricht Treaty and the introduction of the Euro both created strong incentives for countries to control their budget deficits, and especially in the transitory period in between the two milestones, almost all countries strongly improved their positions. 


\section{References}

Adam, Christopher S., and David L. Bevan, (2003), Staying the Course Maintaining Fiscal Control in Developing Countries, Brookings Institution Trade Forum Conference, 2003

Ahmed, S., (1996), Balanced-Budget Rules and Public Deficits: Evidence from the US States. A Comment, Carnegie-Rochester Conference Series on Public Policy, Vol. 45. pp. 77-87.

Alesina, A. and T. Bayoumi, (1996), The Costs and Benefits of Fiscal Rules: Evidence from US States, NBER Working Paper, No. 5614.

Alesina, A. and R. Perotti, (1995), The Political Economy of Budget Deficits, IMF Staff Papers, Vol. 4 2. No. 1.pp. 1-31.

Alesina, A. and R. Perotti, (1995), Fiscal Expansions and Adjustments in OECD Countries, Economic Policy, No. 2 1.pp. 1-42.

Alesina, A. and R. Perotti, (1996), Fiscal Discipline and the Budget Process, American Economic Review, Vol. 86. No. 2. pp. 401-407.

Alesina, A. and R. Perotti, (1996), Budget Deficits and Budget Institutions, NBER Working Paper, No. 5556.

Alesina, A. and R. Perotti, (1997), Fiscal Adjustments in OECD Countries: Composition and Macroeconomic Effects, IMF Staff Papers, Vol. 44. No. 2. pp. 210-248.

Allison, Paul D., (1995), Survival Analysis Using the SAS System: A Practical Guide, Cary, NC (US), SAS Institute Inc.

Ballabriga, F.C. and C. Martinez-Mongay, (2005), Sustainability of EU Public Finances, European Economy - Economic Papers, European Commission (DC ECFIN), No. 225

Barry, F. and M. B. Devreux, (1995), The Expansionary Fiscal Contraction Hypothesis: A NeoKeynesian Analysis, Oxford Economic Papers, Vol. 47. No. 3. pp. 249-264.

Bartolini, L., A. Razin, and S. Symansky, (1995), G7 Fiscal Restructuring in the 1990s: Macroeconomic Effects, Economic Policy, No. 2 0. pp. 109-146.

Bayar, Ali H., (2001), Entry and Exit Dynamics of 'Excessive Deficits' in the European Union, Public Finance \& Management, Vol. 1. No. 1. pp. 92-112

Bayar, A. H., A. Dramais, W. Roeger, and J. in t Veld, (1997), Macroeconomic Effects of Fiscal Restructuring in Europe, in Hairault, J.-O., P.-Y. Hénin, and F. Portier, Business Cycles and Macroeconomic Stability, Kluwer Academic Publishers, Boston, pp. 321-336.

Bayoumi, T. and B. Eichengreen, (1995), Restraining Yourself: The Implications of Fiscal Rules for Economic Stabilization, IMF Staff Papers, Vol. 4 2. No. 1. pp. 32-48.

Bertola, G. and A. Drazen, (1993), Trigger Points and Budget Cuts: Explaining the Effects of Fiscal Austerity, American Economic review, Vol. 83. No. 1. pp. 11-26.

Bohn, H. and R. P. Inman, (1996), Balanced-Budget Rules and Public Deficits: Evidence from the US States, Carnegie-Rochester Conference Series on Public Policy, Vol. 45. pp. 13-76. 
Buiter, W., G. Corsetti, and N. Roubini, (1993), Excessive Deficits: Sense and Nonsense in the Treaty of Maastricht, Economic Policy, No. 16. pp. 58-100.

Buti, M., D. Franco, and H. Ongena, (1997), Budgetary Policies during Recessions. Retrospective Application of the Stability and Growth Pact to Post-War Period, Economic Papers, European Commission, No. 121.

Buti, M., W. Roeger and A. Turrini, (2007), Is Lisbon far from Maastricht? Trade-offs and Complementarities between Fiscal Discipline and Structural Reforms, CEPR Discussion Papers, European Commission, No. 6062

Corsetti, G. and N. Roubini, (1996), European versus American Perspectives on BalancedBudget Rules, American Economic Review, Vol. 86. No. 2. pp. 408-413.

Cour, Ph. E. Dubois, S. Mahfouz, and J. Pisani-Ferry, (1996), The Cost of Fiscal Retrenchment Revisited: How Strong is the Evidence?, INSEE, Document de travail, No. G 9612.

Cox, D. R., (1972), Regression Models and Life Tables, Journal of the Royal Statistical Society, Vol. B 34. pp. 187-220.

Fischer, J., L. Jonung and M. Larch, (2006), 101 Proposals to reform the Stability and Growth Pact. Why so many? A Survey, European Economy - Economic Papers, European Commission (DC ECFIN), No. 267

Giavazzi, F. and M. Pagano, (1990), Can Severe Fiscal Contractions be Expansionary? A Tale of Two Small Economies, in: Blanchard, O. B. and S. Fischer (Eds.), NBER Macroeconomics Annual, pp. 75-110.

Giavazzi, F. and M. Pagano, (1995), Non-Keynesian Effects of Fiscal Policy Changes: More International Evidence, Paper presented at the conference Growing Government Debt: International Experiences, Stockholm, 12 June 1995.

Grilli, V., D. Masciandaro, and G. Tabellini, Institutions and Policies, Economic Policy, No. 13. pp.341-392.

Gupta, S., E. Baldacci, B. Clements and E.R. Tiongson, (2003), What Sustains Fiscal Consolidations in Emerging Market Countries?, IMF Working Paper, WP/03/224

Heylen, F., (1997), A Contribution to the Empirical Analysis of the Effects of Fiscal Consolidation: Explanation of Failure in Europe in the 1990s, paper presented at the conference Public Deficits and Monetary Union, November 27-28. Rome.

Hughes Hallett, A. J. and P. McAdam, (1997), Large Scale Fiscal Contractions in Europe: The Costs, Benefits and Likely Outcomes, Manuscript, University of Strathclyde.

Illera, R. M. and C. Mulas-Granados, (2002), Duration of Fiscal Budgetary Consolidations in the European Union, EEG Working Paper, No. 18/2002

Lancaster, T., (1990), The Econometric Analysis of Transition Data, Cambridge, Cambridge University Press. 
Masson, P. R., (1996), Fiscal Dimensions of EMU, Economic Journal, Vol. 106. No. 437. pp.996-1004.

McDermott, C. J. and R. F. Wescott, (1996), An Empirical Analysis of Fiscal Adjustments, IMF Staff Papers, Vol. 43. No. 4. pp. 725-753.

Perotti, R., (1996), Fiscal Consolidation in Europe: Composition Matters, American Economic Review, Vol. 86. No. 2. pp. 105-110.

Poterba, J. M., (1996), Budget Institutions and Fiscal Policy in the US States, American Economic Review, Vol. 86. No. 2. pp. 395-400.

Roubini, N. and J. D. Sachs, (1989), Political and Economic Determinants of Budget Deficits in the Industrial Democracies, European Economic Review, Vol. 33. No. 5. pp. 903-938.

Roubini, N., (1995), The Economics of Fiscal Bondage: The Balanced Budget Amendment and Other Binding Fiscal Rules, Manuscript, Yale University.

von Hagen, J., (1992), Budgeting Procedures and Fiscal Performance in the European Communities, Economic Papers, Commission of the European Communities, No. 96.

Von Hagen, J., A. Hughes Hallett and R. Strauch, (2002), Budgetary Consolidation in Europe: Quality, Economic Conditions, and Persistence, Journal of the Japanese and International Economies, No. 16. pp. 512-535 
Appendix: Graphs
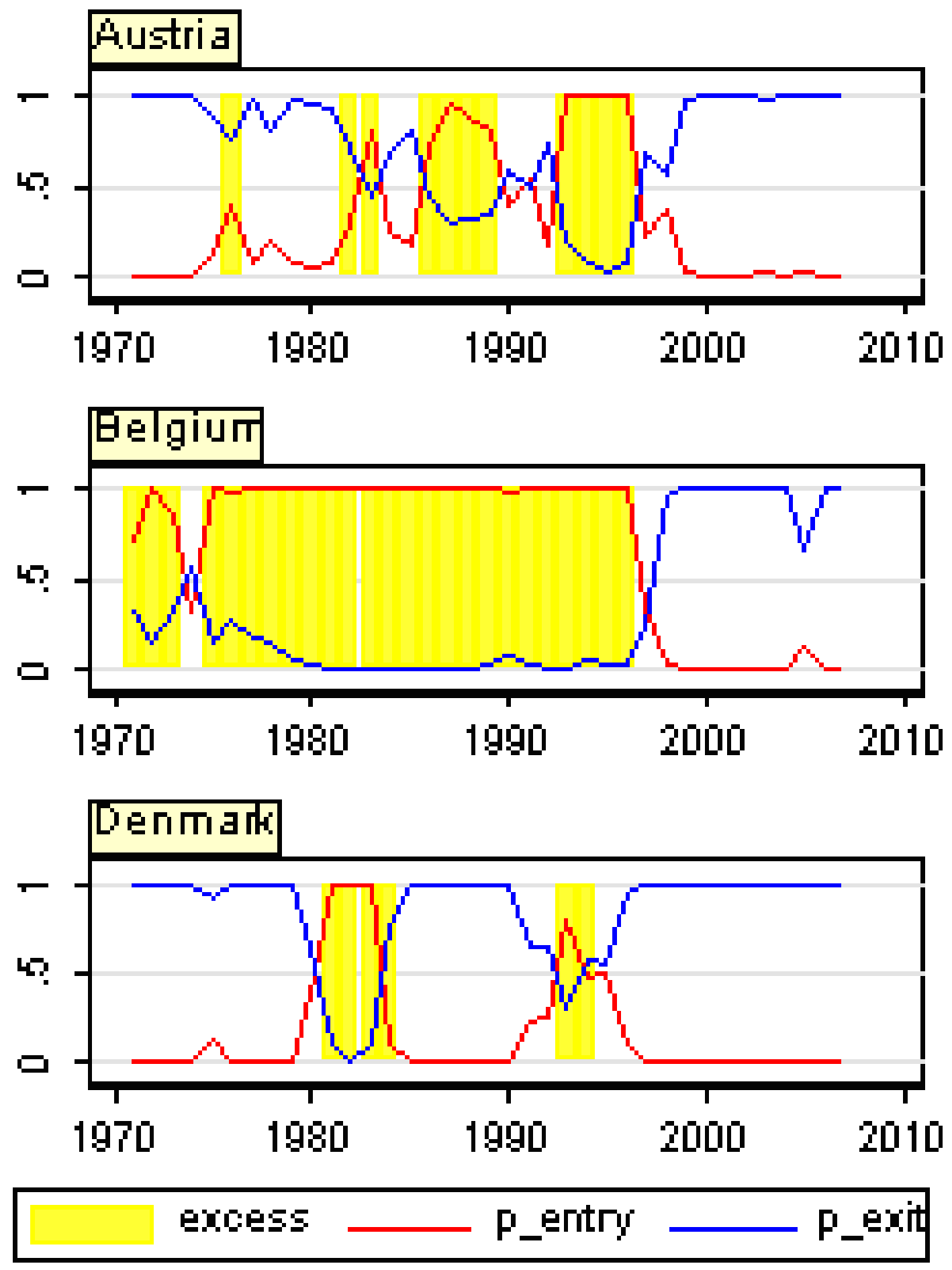

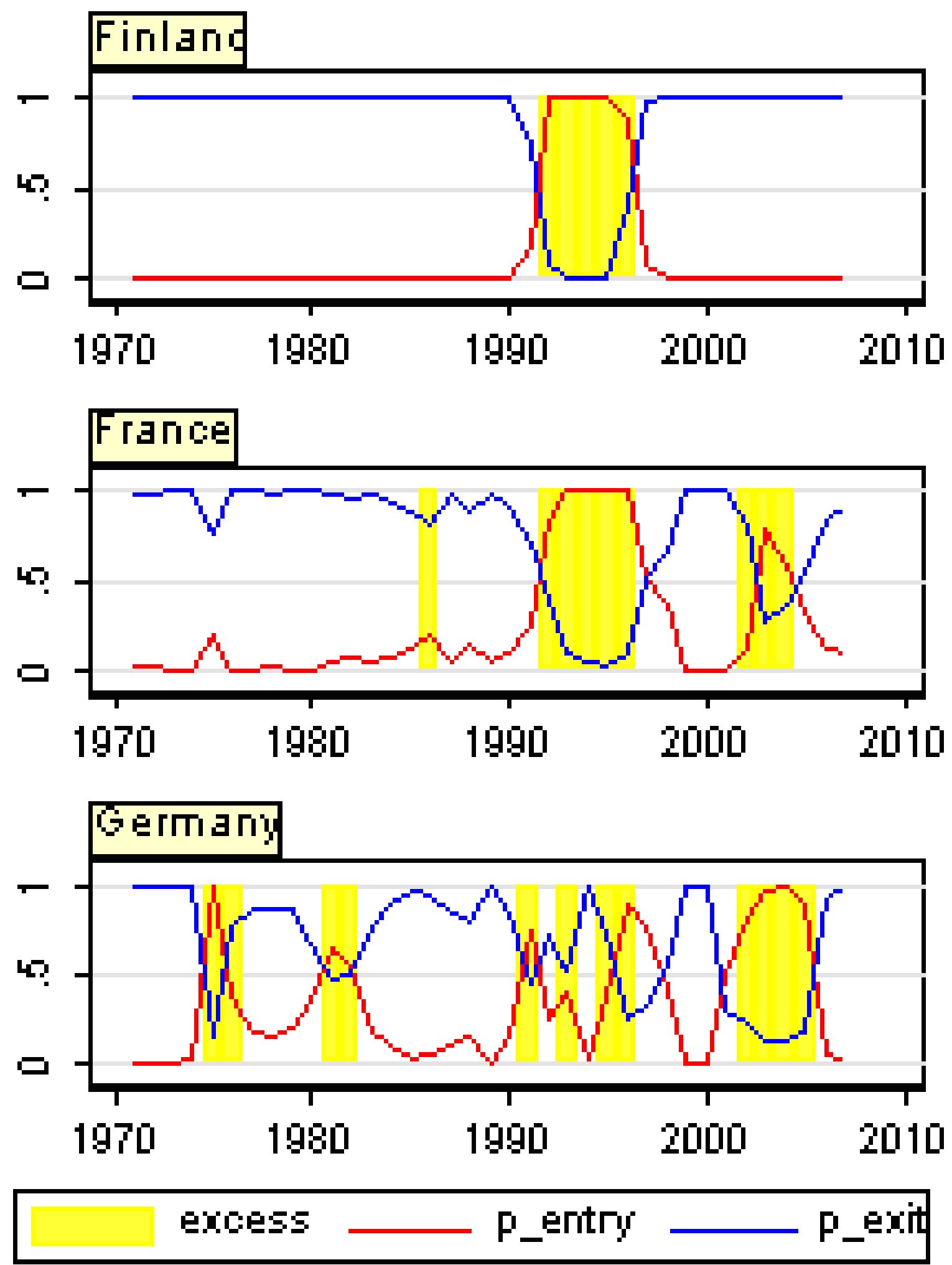

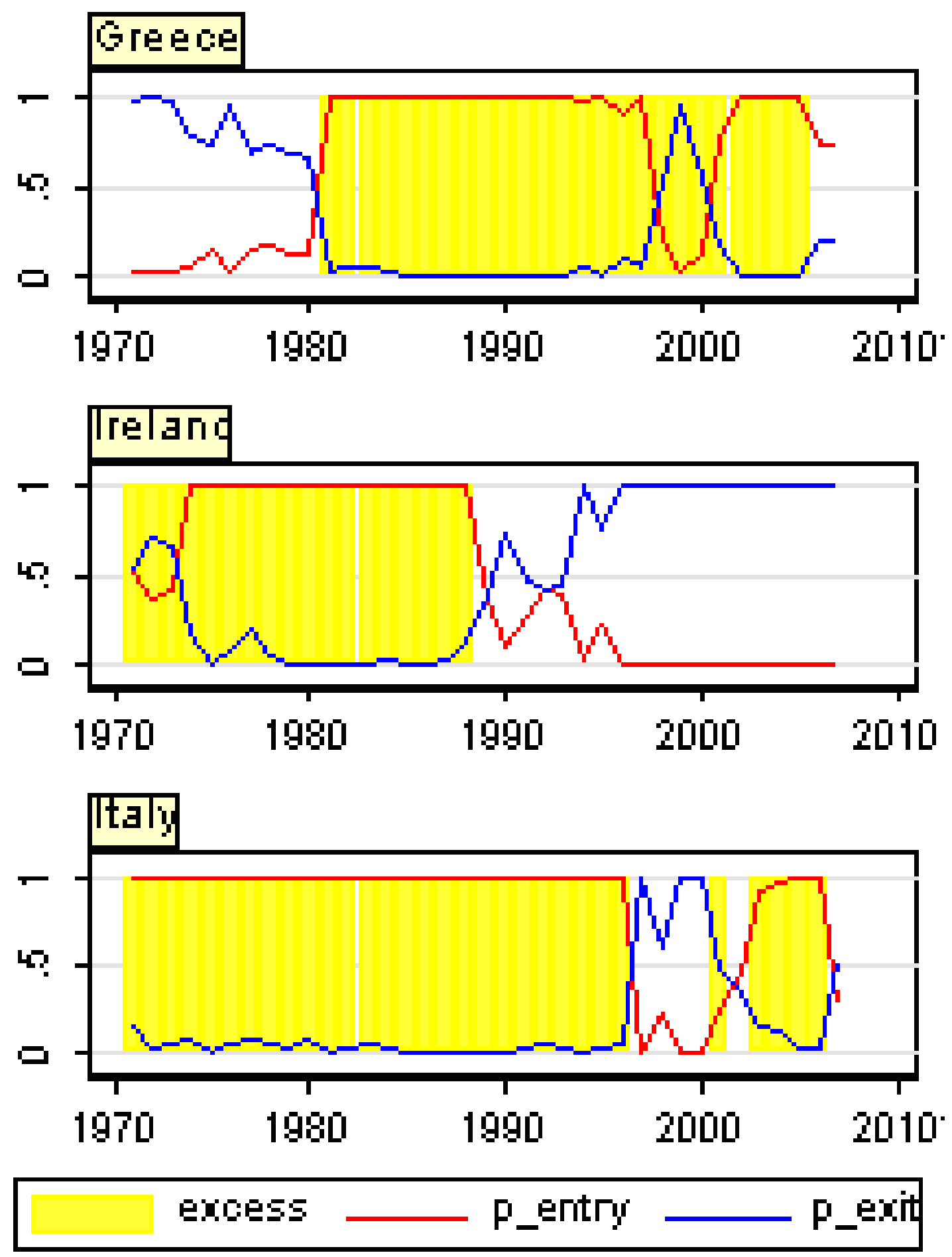

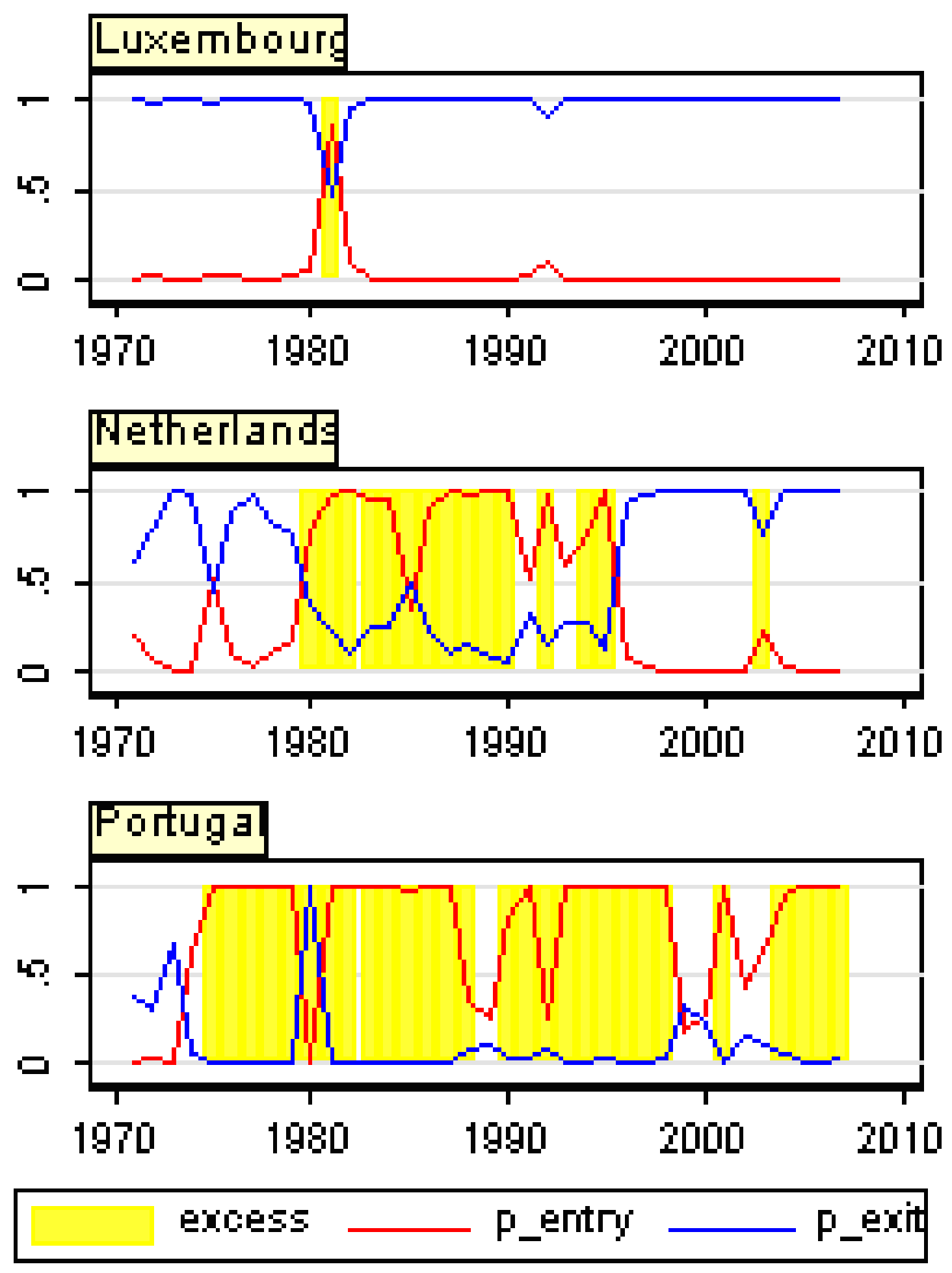

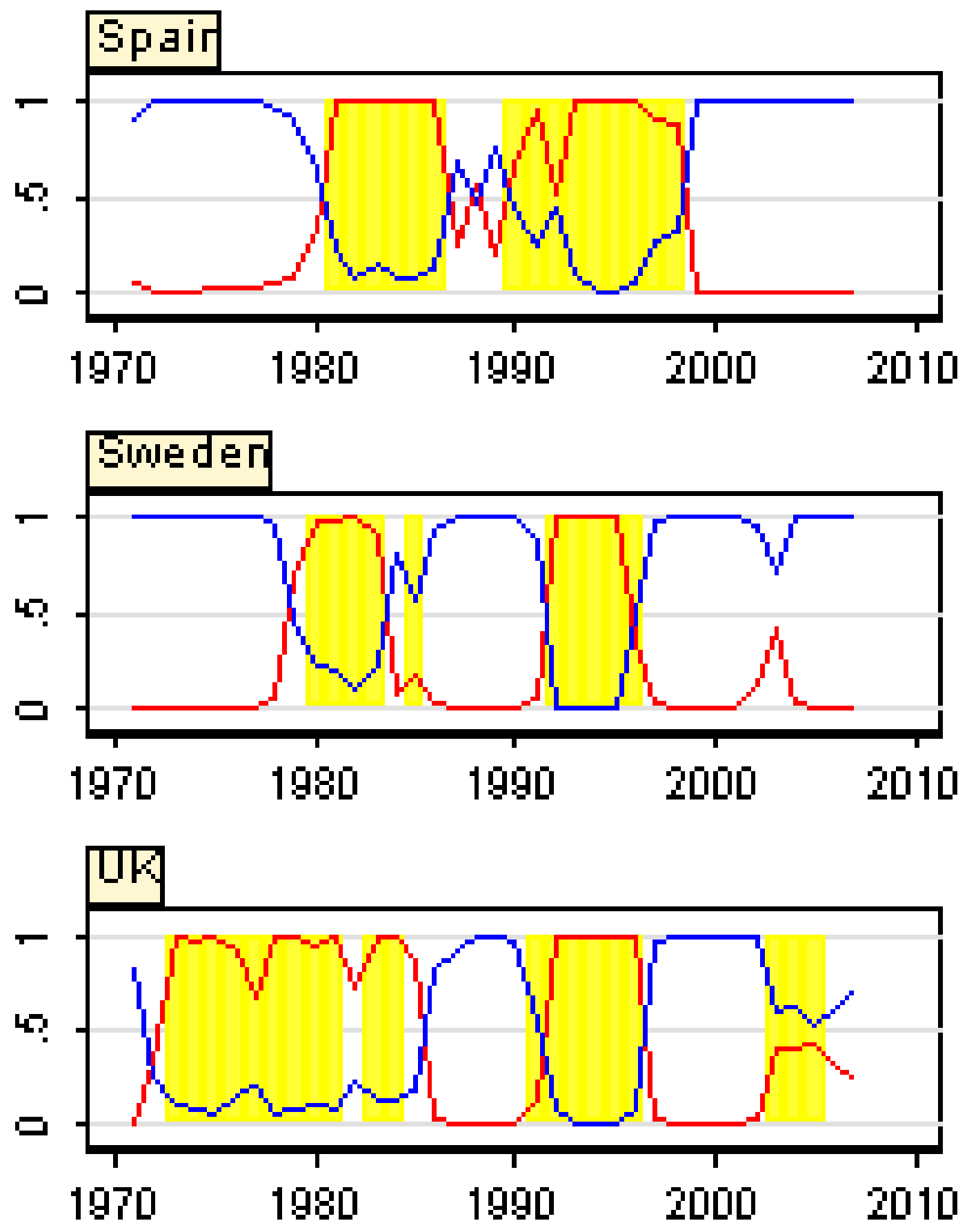


\section{CESifo Working Paper Series}

for full list see www.cesifo-group.org/wp

(address: Poschingerstr. 5, 81679 Munich, Germany, office@cesifo.de)

2641 Martin Halla, Mario Lackner and Friedrich G. Schneider, An Empirical Analysis of the Dynamics of the Welfare State: The Case of Benefit Morale, May 2009

2642 Balázs Égert, Infrastructure Investment in Network Industries: The Role of Incentive Regulation and Regulatory Independence, May 2009

2643 Christian Gollier, Expected Net Present Value, Expected Net Future Value, and the Ramsey Rule, May 2009

2644 Sören Blomquist and Håkan Selin, Hourly Wage Rate and Taxable Labor Income Responsiveness to Changes in Marginal Tax Rates, May 2009

2645 Dominique Demougin, Oliver Fabel and Christian Thomann, Implicit vs. Explicit Incentives: Theory and a Case Study, May 2009

2646 Francesco C. Billari and Vincenzo Galasso, What Explains Fertility? Evidence from Italian Pension Reforms, May 2009

2647 Kjell Arne Brekke, Karen Evelyn Hauge, Jo Thori Lind and Karine Nyborg, Playing with the Good Guys - A Public Good Game with Endogenous Group Formation, May 2009

2648 Guglielmo Maria Caporale and Luis A. Gil-Alana, Multi-Factor Gegenbauer Processes and European Inflation Rates, May 2009

2649 Henning Bohn, A Static Model for Voting on Social Security, May 2009

2650 Markus Haavio and Kaisa Kotakorpi, The Political Economy of Sin Taxes, May 2009

2651 Augusto de la Torre, María Soledad Martínez Pería and Sergio L. Schmukler, Drivers and Obstacles to Banking SMEs: The Role of Competition and the Institutional Framework, May 2009

2652 Tobias Lindhe and Jan Södersten, Dividend Taxation, Share Repurchases and the Equity Trap, May 2009

2653 Assaf Razin and Edith Sand, Migration-Regime Liberalization and Social Security: Political-Economy Effect, May 2009

2654 Yin-Wong Cheung and Hiro Ito, A Cross-Country Empirical Analysis of International Reserves, May 2009

2655 Bart Cockx and Bruno Van der Linden, Flexicurity in Belgium. A Proposal Based on Economic Principles, May 2009 
2656 Michael Melvin, Lukas Menkhoff and Maik Schmeling, Exchange Rate Management in Emerging Markets: Intervention via an Electronic Limit Order Book, May 2009

2657 Susanne Neckermann, Reto Cueni and Bruno S. Frey, What is an Award Worth? An Econometric Assessment of the Impact of Awards on Employee Performance, May 2009

2658 Steven Brakman, Harry Garretsen and Charles van Marrewijk, Economic Geography within and between European Nations: The Role of Market Potential and Density across Space and Time, May 2009

2659 Giovanni Facchini and Cecilia Testa, Reforming Legislatures: Is one House better than two?, May 2009

2660 Carsten Kowalczyk and Raymond Riezman, Trade Agreements, May 2009

2661 Oliver Falck, Stephan Heblich and Elke Luedemann, Identity and Entrepreneurship, May 2009

2662 Christian Lessmann and Gunther Markwardt, One Size Fits All? Decentralization, Corruption, and the Monitoring of Bureaucrats, May 2009

2663 Felix Bierbrauer, On the Legitimacy of Coercion for the Financing of Public Goods, May 2009

2664 Alessandro Cigno, Agency in Family Policy: A Survey, May 2009

2665 Claudia M. Buch and Christian Pierdzioch, Low Skill but High Volatility?, May 2009

2666 Hendrik Jürges, Kerstin Schneider, Martin Senkbeil and Claus H. Carstensen, Assessment Drives Learning: The Effect of Central Exit Exams on Curricular Knowledge and Mathematical Literacy, June 2009

2667 Eric A. Hanushek and Ludger Woessmann, Schooling, Cognitive Skills, and the Latin American Growth Puzzle, June 2009

2668 Ourania Karakosta, Christos Kotsogiannis and Miguel-Angel Lopez-Garcia, Does Indirect Tax Harmonization Deliver Pareto Improvements in the Presence of Global Public Goods?, June 2009

2669 Aleksandra Riedl and Silvia Rocha-Akis, Testing the Tax Competition Theory: How Elastic are National Tax Bases in OECD Countries?, June 2009

2670 Dominique Demougin and Carsten Helm, Incentive Contracts and Efficient Unemployment Benefits, June 2009

2671 Guglielmo Maria Caporale and Luis A. Gil-Alana, Long Memory in US Real Output per Capita, June 2009 
2672 Jim Malley and Ulrich Woitek, Productivity Shocks and Aggregate Cycles in an Estimated Endogenous Growth Model, June 2009

2673 Vivek Ghosal, Business Strategy and Firm Reorganization under Changing Market Conditions, June 2009

2674 Francesco Menoncin and Paolo M. Panteghini, Retrospective Capital Gains Taxation in the Real World, June 2009

2675 Thomas Hemmelgarn and Gaëtan Nicodème, Tax Co-ordination in Europe: Assessing the First Years of the EU-Savings Taxation Directive, June 2009

2676 Oliver Himmler, The Effects of School Competition on Academic Achievement and Grading Standards, June 2009

2677 Rolf Golombek and Michael Hoel, International Cooperation on Climate-Friendly Technologies, June 2009

2678 Martin Cave and Matthew Corkery, Regulation and Barriers to Trade in Telecommunications Services in the European Union, June 2009

2679 Costas Arkolakis, A Unified Theory of Firm Selection and Growth, June 2009

2680 Michelle R. Garfinkel, Stergios Skaperdas and Constantinos Syropoulos, International Trade and Transnational Insecurity: How Comparative Advantage and Power are Jointly Determined, June 2009

2681 Marcelo Resende, Capital Structure and Regulation in U.S. Local Telephony: An Exploratory Econometric Study; June 2009

2682 Marc Gronwald and Janina Ketterer, Evaluating Emission Trading as a Policy Tool Evidence from Conditional Jump Models, June 2009

2683 Stephan O. Hornig, Horst Rottmann and Rüdiger Wapler, Information Asymmetry, Education Signals and the Case of Ethnic and Native Germans, June 2009

2684 Benoit Dostie and Rajshri Jayaraman, The Effect of Adversity on Process Innovations and Managerial Incentives, June 2009

2685 Peter Egger, Christian Keuschnigg and Hannes Winner, Incorporation and Taxation: Theory and Firm-level Evidence, June 2009

2686 Chrysovalantou Milliou and Emmanuel Petrakis, Timing of Technology Adoption and Product Market Competition, June 2009

2687 Hans Degryse, Frank de Jong and Jérémie Lefebvre, An Empirical Analysis of Legal Insider Trading in the Netherlands, June 2009

2688 Subhasish M. Chowdhury, Dan Kovenock and Roman M. Sheremeta, An Experimental Investigation of Colonel Blotto Games, June 2009 
2689 Alexander Chudik, M. Hashem Pesaran and Elisa Tosetti, Weak and Strong Cross Section Dependence and Estimation of Large Panels, June 2009

2690 Mohamed El Hedi Arouri and Christophe Rault, On the Influence of Oil Prices on Stock Markets: Evidence from Panel Analysis in GCC Countries, June 2009

2691 Lars P. Feld and Christoph A. Schaltegger, Political Stability and Fiscal Policy - Time Series Evidence for the Swiss Federal Level since 1849, June 2009

2692 Michael Funke and Marc Gronwald, A Convex Hull Approach to Counterfactual Analysis of Trade Openness and Growth, June 2009

2693 Patricia Funk and Christina Gathmann, Does Direct Democracy Reduce the Size of Government? New Evidence from Historical Data, 1890-2000, June 2009

2694 Kirsten Wandschneider and Nikolaus Wolf, Shooting on a Moving Target: Explaining European Bank Rates during the Interwar Period, June 2009

2695 J. Atsu Amegashie, Third-Party Intervention in Conflicts and the Indirect Samaritan's Dilemma, June 2009

2696 Enrico Spolaore and Romain Wacziarg, War and Relatedness, June 2009

2697 Steven Brakman, Charles van Marrewijk and Arjen van Witteloostuijn, Market Liberalization in the European Natural Gas Market - the Importance of Capacity Constraints and Efficiency Differences, July 2009

2698 Huifang Tian, John Whalley and Yuezhou Cai, Trade Sanctions, Financial Transfers and BRIC's Participation in Global Climate Change Negotiations, July 2009

2699 Axel Dreher and Justina A. V. Fischer, Government Decentralization as a Disincentive for Transnational Terror? An Empirical Analysis, July 2009

2700 Balázs Égert, Tomasz Koźluk and Douglas Sutherland, Infrastructure and Growth: Empirical Evidence, July 2009

2701 Felix Bierbrauer, Optimal Income Taxation and Public Goods Provision in a Large Economy with Aggregate Uncertainty, July 2009

2702 Marc Gronwald, Investigating the U.S. Oil-Macroeconomy Nexus using Rolling Impulse Responses, July 2009

2703 Ali Bayar and Bram Smeets, Government Deficits in the European Union: An Analysis of Entry and Exit Dynamics, July 2009 